Biogeosciences Discuss., https://doi.org/10.5194/bg-2018-428

Manuscript under review for journal Biogeosciences

Discussion started: 29 October 2018

(c) Author(s) 2018. CC BY 4.0 License.

\title{
Microbial Community Function in Electroactive Biofilm-based Constructed Wetlands
}

\author{
Carlos A. Ramírez-Vargas ${ }^{1,2}$, Carlos A. Arias ${ }^{1,2}$, Liang Zhang ${ }^{1,2}$, Hans Brix ${ }^{1,2}$ \\ ${ }^{1}$ Department of Bioscience, Aarhus University, 8000 Aarhus C, Denmark \\ $5 \quad{ }^{2}$ WATEC, Aarhus University, 8000 Aarhus C, Denmark
}

Correspondence to: Carlos A. Ramírez-Vargas ${ }^{1,2}$ (c.a.ramirez@bios.au.dk)

\begin{abstract}
The performance enhancement of constructed wetlands can be achieved through the coupling with microbial electrochemical technologies (MET). MET is a setup designed to mimic metabolic electrons exchange with insoluble donors and acceptors with the aid of electroactive bacteria and external electrical circuits. An alternative MET that dispenses of electrodes and circuits but uses an electro-conductive biofilter is called Microbial Electrochemical-based Constructed Wetland (METland). Previously it has been demonstrated that a METland has higher biodegradation rates than horizontal flow constructed wetlands, however given its novelty there are still uncertainties related to the removal of pollutants, including their microbial activity. The genetic characterization of microbial communities of a METland is desirable, but is time and resource consuming, then a characterization alternative could be based on functional analysis of the microbial communities.

15 Community-level physiological profile (CLPP) is a useful method to evaluate the functional diversity of microbial communities based on the carbon source utilization pattern (CSUP). Therefore, this study was focused on the microbial characterization of laboratory scale METland based on CLPP analysis. The study included the characterization of microbial communities attached to two carbon-based electro-conductive materials (calcined petroleum coke from crushed electrodes PK-A; calcined petroleum coke with low sulphur and nitrogen content - PK-LSN), in planted and non-planted set-ups.

20 Variations on the metabolic activity of tested systems were identified and it seems to be related to the characteristics of the material, rather than the presence / absence of plants. In general, CSUP show differences along flow pathway, as well as among the tested systems, being carbohydrates and carboxylic/acetic acids the most consumed carbon sources, followed by polymers, amides/amines and amino acids. Also, were established some correlations between the utilization of carbon sources and the removal of pollutants. The obtained results provide useful insight into the spatial dynamics of METland systems.
\end{abstract}

\section{Introduction}

Constructed wetlands are biological engineered system designed to optimize the processes that occur in natural wetlands, with the aim of treating wastewaters in a sustainable and environmental friendly way (Dotro et al., 2017). The performance of constructed wetlands relies on the interaction of physical, chemical and biological processes, the presence of plants and microorganisms, and removal mechanisms such as precipitation, sedimentation, filtration, volatilization, adsorption, plant 
Biogeosciences Discuss., https://doi.org/10.5194/bg-2018-428

Manuscript under review for journal Biogeosciences

Discussion started: 29 October 2018

(c) Author(s) 2018. CC BY 4.0 License.

uptake and microbial-driven degradation (Kadlec and Wallace, 2009). These processes are determined by operative settings (loading rates, loading pattern, etc.) and environmental conditions inside the wetland bed (eg. substrate type, $\mathrm{pH}$, temperature, dissolved oxygen, and Redox conditions) (Wu et al., 2014a)

Constructed wetlands are designed to effectively treat raw, primary, secondary or tertiary treated wastewaters from different

5 origins (Dotro et al., 2017), such as domestic, industrial, drainage mining, runoff and agriculture effluents (Ghobrial, 2008; Nivala et al., 2012; Paredes et al., 2007; Reed et al., 1995; Vymazal, 2014). Constructed wetlands can be classified according to the dominant macrophytes (free-floating, floating leaved, rooted emergent and submerged), hydrology (surface or subsurface flow) and flow direction (horizontal or vertical) (Vymazal, 2010). Constructed wetlands are robust and costeffective technology that require low operation and maintenance efforts (Brix et al., 2007; Vymazal, 2009; Masi et al., 2018)

10 being used worldwide as a mature solution for decentralized wastewater treatment (Langergraber and Masi, 2018). However, the major drawback of constructed wetlands implementation is its area footprint, much larger than other compact wastewater treatment technology. Therefore, to reduce the surface requirements, constructed wetlands have been evolving from passive to intensified systems (S. Wu et al., 2014), including very recent designs that incorporate the combination of constructed wetlands with microbial electrochemical technologies (MET) (Wang et al., 2017c).

15 MET are applications of microbial-driven electrochemical processes either for the production of complex organic compounds, energy generation or environmental solutions (Schröder et al., 2015). MET rely on the action of electroactive bacteria, which are microorganisms with the ability to conserve energy from electron transfer to an electron acceptor (e.g. a solid-state electrode) (Borole et al., 2011). Electroactive bacteria have been found in several substrates including marine/fresh water sediments (Lovley, 2008; Risgaard-Petersen et al., 2014; Sajana et al., 2013), manure (Min et al., 2005; Vilajeliu-Pons et al.,

20 2015), aerobic/anaerobic wastewater treatment sludge (Gao et al., 2014; Lobato et al., 2012; Villano et al., 2012), and wastewater (Escapa et al., 2014; Velvizhi \& Venkata Mohan, 2015).

The presence of Redox gradients along a constructed wetland depth profile, led to explore the possibility of combining them with MET, as it was done in microbial fuel cells (MFC) for simultaneous production of energy and wastewater treatment (Yadav et al., 2012). Similarly to conventional MFC, a constructed wetland-MFC (CW-MFC) is a set-up fitted with an anode,

25 located in the anaerobic zone (bottom), and a cathode in the anoxic/aerobic zone (top) of a permanent flooded bed (Doherty et al., 2015). Electroactive bacteria consume organic compounds in the anaerobic zone and release electrons that are transferred to the anode. From the anode, the electrons flow along an external circuit to the cathode, where the released electrons can be used in the reduction of $\mathrm{O}_{2}$ or $\mathrm{NO}_{3}$. The charge balance is completed either by incorporating an ion separator or simply by allowing ions to flow in the bulk fluid (Ramirez-Vargas et al., 2018)

30 Most recent developments on CW-MFC has dispensed of external circuits to rely merely on the presence of electro-conductive substrate performing as single-piece electrode, therefore operating in a short-circuit mode. This approach has led to the creation of microbial electrochemical-based CW (METlands). In a METland system, the electroactive bacteria are stimulated to generate and transfer electrons to an electro-conductive material acting as unlimited electron acceptor, maximizing substrate consumption (Esteve-Núñez, 2015). The METland system has been tested for the removal of organic matter and nitrogen with 
Biogeosciences Discuss., https://doi.org/10.5194/bg-2018-428

Manuscript under review for journal Biogeosciences

Discussion started: 29 October 2018

(c) Author(s) 2018. CC BY 4.0 License.

horizontal subsurface flow coke biofilters at laboratory scale, reaching removal rates above $90 \%$ for $\mathrm{NH}_{4}$ (at 3.5 days of hydraulic retention time), $\mathrm{COD}$ and $\mathrm{BOD}_{5}$ (at 0.5 days hydraulic retention time) (Aguirre-Sierra et al., 2016). Those results suggest that a METland system given the presence of EAB can enhance biodegradation rates, thus allowing the reduction of the area requirements of classical constructed wetlands.

5 It is known that microorganisms are the main driving force in the removal of pollutants under anaerobic and aerobic/anoxic conditions inside constructed wetlands (Faulwetter et al., 2009), and become highly active and dominant if enough substrates exist under suitable environmental conditions (Truu et al., 2009). Most of this microorganism are present as biofilms, attached to the roots of wetland plants or to the surface of the filter media in constructed wetlands (Adrados et al., 2014). In a MET based constructed wetland, the operative conditions and configurations lead to the development of biofilms mainly composed by microorganisms of Proteobacteria, Acidobacteria and Firmicutes genus (Li et al., 2016; J. Wang et al., 2017; F. Xu et al., 2018) (Aguirre-Sierra et al., 2016). These microorganisms have been identified as genus able to build-up electro-conductive biofilms in solid-state electron acceptors (Logan, 2009; Butti et al., 2016).

If constructed wetland technology performance is to be optimized, the microbial composition of the systems must be understood (Button et al., 2015). The genetic characterization of microbial communities of constructed wetlands is desirable,

15 however all microorganisms inside the systems must be identified, task that is time and resource consuming, and may not be of much interest from the engineering point of view (Weber et al., 2008). Therefore it might be more interesting to conduct microbial characterizations based on the functional analysis of the communities inside constructed wetlands (Weber and Gagnon, 2014). The functional diversity of the microorganisms can be assessed using different techniques such as culturebased methods, microbial mass and enzyme assessment, and most recently with community level physiological profiling

20 (CLPP) (Button et al., 2015).

The CLLP method is designed to assess the dynamics of microbial communities based on carbon source utilization patterns of environmental samples (Garland and Mills, 1991). The method involves the direct inoculation of collected samples into plates with wells that contain different carbon sources and tetrazolium as Redox dye indicator (Garland, 1997). When the microbial community consume the carbon sources, nicotinamide adenine dinucleotide (NADH) is released as side produce of cell respiration, reducing the tetrazolium dye into formazan, provoking a color change into wells which could be detected by photometrically devices (Weber and Legge, 2010a). The CLPP method has been implemented in studies of terrestrial and aquatic environments, including the microbial activity of conventional wastewater treatment systems and constructed wetlands (Salomo et al., 2009; Button et al., 2016).

The most common used plate for CLPP analysis is the Biolog ${ }^{\circledR}$ EcoPlate, which contains relevant environmental carbon

30 sources, known to be derived of plant root exudates or that ease the differentiation of soil microbial communities (Insam and Goberna, 2004). Carbon sources can be grouped by composition into carbohydrates, polymers, carboxylic acids, amines/amides, and amino acids (Weber and Legge, 2009), representing a large degree of compounds, which depending on the degree of consumption, can ease the understanding of the functionality of the microbial communities for pollution removal in wastewater treatment systems like constructed wetlands (Button et al., 2016). 
Biogeosciences Discuss., https://doi.org/10.5194/bg-2018-428

Manuscript under review for journal Biogeosciences

Discussion started: 29 October 2018

(c) Author(s) 2018. CC BY 4.0 License.

Given the novelty of the MET based CW, the objective of this study was to assess the impact of different electro-conductive materials on the microbial community function of planted and non-planted METland set-up fed with real wastewater. Biolog ${ }^{\circledR}$ EcoPlates were used to analyze the substrate utilization patterns of the microbial biofilms detached of material samples, considering each tested set-up as a single sample, as well as at different levels inside them. Microbial community function was

5 analyzed based on carbon source utilization patterns (CSUP), derived microbial metabolic indexes (average well color development - AWCD; richness; diversity), and carbon guild utilization. Additionally, the organic matter and nutrients removals were estimated and correlated with CSUP and microbial metabolic indexes.

\section{Methods}

\subsection{Experimental set-up}

10 The experimental setup consisted of 16 columns (h: $50 \mathrm{~cm}$; Ø: $16 \mathrm{~cm}$; packed vol.: $8.44 \mathrm{~L}$ ) installed at Aarhus University's greenhouses (Denmark). Twelve of the columns were filled with two types of electro-conductive materials, 6 columns for calcined petroleum coke from crushed electrodes (PK-A), 6 columns of calcined petroleum coke with low sulphur and nitrogen content (PK-LSN), and 4 columns filled with sand as a control. Half of the columns were planted with Juncus effusus to determine the potential effects of the plants. Each column acted as a replicate to have 6 different sets of planted (P) and non-

15 planted (NP) systems: PK-A/P, PK-A/NP, PK-LSN/P, PK-LSN/NP, Sand/P and Sand/NP. The physical/chemical characteristics of materials are summarized in Table 1 . The columns were continuously up-flow fed for a period of 16 weeks, with primary settled pig manure supplemented with starch and molasses (Table 2).

\subsection{Sample collection and biofilm detachment and CLPP inoculation}

The microbial community function of tested systems was analyzed for the community level physiological profile (CLPP)

20 method, after 16 weeks of operation. To perform the CLPP analysis, $25 \mathrm{~g}$ of filtering media samples were collected with sterile tweezer from 5 different points inside each column (from bottom to top: $0 \mathrm{~cm}$ - inlet zone, $12.5 \mathrm{~cm}, 25.0 \mathrm{~cm}, 37.5 \mathrm{~cm}$, and 45 $\mathrm{cm}$ - outlet zone), and deposited in sterilized Falcon tubes. Given that only two columns were installed per sand treatment, a third sample was composed by mixing them. The biofilm detachment of the collected substrate was based on an adapted version of the protocol described by Weber \& Legge (2010b) as follows. Each media sample was immersed in $100 \mathrm{ml}$ of sterile phosphate buffer solution, and shaken in an orbital shaker (VWR ${ }^{\circledR}$ Advanced Orbital Shaker - VWR International, Pennsylvania, USA) in $500 \mathrm{~mL}$ flasks for $3 \mathrm{~h}$ at $30{ }^{\circ} \mathrm{C}$ at $100 \mathrm{rpm}$. After detachment, the obtained biofilm suspension was diluted with 1:10 PBS for inoculating in CLPP plates.

\subsection{CLPP plates inoculation}

BIOLOG $^{\mathrm{TM}}$ EcoPlates (Biolog Inc., Hayward CA, USA) analysis were used for CLPP analysis. The plates contain 31 wells carbon substrates and 1 as blank, all of them in triplicate. Based on an adaptation of the protocol described by Weber \& Legge 
Biogeosciences Discuss., https://doi.org/10.5194/bg-2018-428

Manuscript under review for journal Biogeosciences

Discussion started: 29 October 2018

(c) Author(s) 2018. CC BY 4.0 License.

(2010a) the inoculation of the EcoPlates was done in a sterile laminar flow hood (Labogene SCANLAF MARS), with materials cleaned with $70 \%$ ethanol. In total, 30 EcoPlates (5 heights x 6 system types) were inoculated. The EcoPlates were inoculated with $100 \mu \mathrm{L}$ of diluted biofilm suspension using a multichannel pipette (GILSON® Pipetman ${ }^{\circledR}$ L P8X200L). After inoculation, the initial optical density (measure of light absorbance of the Redox dye indicator of the wells) of the plates was

5 measured using a BIOLOG ${ }^{\mathrm{TM}}$ MicroStation absorbance reader (Biolog Inc., Hayward CA, USA) at an absorbance of $590 \mathrm{~nm}$. After the first measure, the EcoPlates were inoculated in dark conditions at $21 \mathrm{C}^{\circ}$, and shaken at $100 \mathrm{rpm}$ with the same orbital shaker used for the biofilm detachment. After the initial inoculation, the optical density of EcoPlates was measured every 4 hours for a period of 5 days.

\subsection{CLPP data processing}

10 CLPP data processing and analysis was done based on the procedures described by Weber et al. (2007) and Weber \& Legge (2010a). Given that optical density values above 2 are outside of the linear absorbance range, the analysis of the CLPP data was performed based on the selection of a single time point of 48 hours. This time provided the greatest variance and the lowest average of wells with optical density values above 2 , therefore minimizing the errors for the later data analysis.

From the data collected at that time point, three different microbial metabolic indexes derived of CSUP data were selected for

15 the CLPP analysis: $i$ ) average well color development (AWCD), ii) substrate richness (S) and iii) Shannon's diversity index (H). The AWCD resembles the average metabolic activity (substrate utilization) of all wells of a plate at a given time (Eq. 1). The substrate richness (S), refers to the metabolic potential of a microbial community for consuming different carbon sources (Eq. 2). The Shannon's diversity index (H), encompasses the richness and evenness of substrate utilization of a given microbial community (Eq. 3):

$20 A W C D=\frac{1}{31} \sum_{\mathrm{i}=1}^{31}\left(A_{i}-A_{0}\right)$,

$S=\sum_{\mathrm{i}=1}^{31}\left(\right.$ well $\left._{i}\right) ;$ if $\left(A_{i}-A_{o}\right)>0.25$,

$H=-\sum p_{i}\left(\ln p_{i}\right)$

where $A_{i}$ is the optical density absorbance value of well $i, A_{o}$ is the optical density absorbance value of blank well, and $p_{i}$ is the ratio of the activity of a given substrate to the sums of all the substrates activity.

25 Given that the CLPP analysis of this study is based on the use of numerous plates ( 30 EcoPlates $=6$ systems x 5 levels/heights), and a single time point of 48 hours was selected as base for analysis, an initial standardization of the data was done to reduce any biased result, due to inoculum density differences between samples. The standardization was carried out based on Eq. 4 (Garland, 1997; Weber \& Legge, 2010a):

$\hat{\mathrm{A}}_{k}=\frac{A_{k}-A_{0}}{\mathrm{AWCD}}$ 
Biogeosciences Discuss., https://doi.org/10.5194/bg-2018-428

Manuscript under review for journal Biogeosciences

Discussion started: 29 October 2018

(c) Author(s) 2018. CC BY 4.0 License.

where $\hat{A}_{k}$ is the optical density absorbance value of well $k, A_{o}$ is the optical density absorbance value of blank well, and AWCD is the average well color development previously calculated.

To simplify the study of CSUP, after the data transformation, the 31 carbon sources were classified into five specific groups (Weber and Legge, 2009): i) polymers; ii) carbohydrates; iii) carboxylic and acetic acids; iv) amino acids; and v)

5 amines/amides. To carry out principal component analyses (PCA), and after the assessment of normality, homoscedasticity and linear correlations following the protocol established by Weber et al. (2007), the CSUP data were subjected to a Taylor transformation.

\subsection{Sampling and analysis of water quality parameters}

The removal of organic matter and nutrients was tested by the collection of grab samples of influent and effluent for a period

10 of 16 weeks. In-situ measurements using calibrated electrodes included pH (Hach PHC101), electrical conductivity (Hach sensION+ 5060), temperature, dissolved oxygen (Hach LDO101) and Redox potential from water samples (Hach MTC101). Chemical oxygen demand (COD) analysis were carried out by photometric evaluation (Hach LCI 400 cuvette test + DR 3900 spectrophotometer), biological oxygen demand $\left(\mathrm{BOD}_{5}\right)$ analysis by respirometric method (WTW OxiTOP®), and total suspended solids (TSS) by standard methods 2540 D (APHA 2012). Total organic carbon (TOC) and total nitrogen (TN) were

15 analyzed through combustion catalytic oxidation/NDRI method (Shimadzu TOC-VCPH), and orthophosphates ( $\left.\mathrm{PO}_{4}-\mathrm{P}\right)$, ammonia $\left(\mathrm{NH}_{4}-\mathrm{N}\right)$ and nitrates $\left(\mathrm{NO}_{3}-\mathrm{N}\right)$ by ion chromatography (Lachat QuickChem $\left.{ }^{\circledR} 8000\right)$. Additionally, to consider the impact of evapotranspiration (Etp) on the removal efficiency $(E)$ of the system, water and mass balances were measured between inlet and according to Eq. 5 and 6.

$E t p=\frac{V_{\text {in }}-V_{\text {out }}}{V_{\text {in }}} \times 100 \%$,

$20 E=\frac{C_{\text {in }} \times V_{\text {in }}-C_{\text {out }} \times V_{\text {out }}}{C_{\text {in }} \times V_{\text {in }}} \times 100 \%$,

where $V_{\text {in }}$ and $V_{\text {out }}$ correspond to inlet and outlet volume, $C_{\text {in }}$ and $C_{\text {out }}$ are the inlet and outlet concentration of the assessed pollutants.

\subsection{Statistical analysis}

The statistical analysis was carried out using XLSTAT 19.02 software. The CSUP data were analyzed using the principal component analysis (PCA), considering as active variables the established 5 carbon guilds, as auxiliary variable the level from where samples were collected inside the systems, and as objects each of the sampled points per tested system ( $\mathrm{n}=90$ samples). The differences in microbial community metabolic profiles among the columns in the PCA plots were evaluated by one-way permutational analysis of variance (PERMANOVA) with a significance level of $P<0.05$ using the paleontological statistic software package (PAST) (Hammer et al., 2001). 
Biogeosciences Discuss., https://doi.org/10.5194/bg-2018-428

Manuscript under review for journal Biogeosciences

Discussion started: 29 October 2018

(c) Author(s) 2018. CC BY 4.0 License.

To test the statistical significance of the differences among means of AWCD, richness, and diversity, the data were submitted to an ANOVA test with significance level of $P<0.05$, followed by post-hoc Tukey's HSD test to detect specific differences between systems. The same procedure was followed to identified significant differences on the carbo guild consumption among tested systems and water quality parameters. Additionally, a correlation analysis of CSUP indexes, carbon guild consumption

5 and removal efficiencies, was carried out based on the use of correlation PCA correlation biplots.

The PCA is a multivariate analysis method that ease the study of multidimensional datasets of quantitative variables (carbon guild utilization), by projecting them in a 2-dimensional chart (factors). The resulting PCA chart allows to visualize the objects under study (tested systems), and depending on their position on the charts, let to establish their relationship with the quantitative variables. The correlation between variables under study can be determined by the angles formed between them.

10 Acute angles indicate that the variables are correlated, right angles indicate that the variables not correlated, and obtuse angles indicate that the variables inversely correlated.

\section{Results and Discussion}

\subsection{Influence of type of system on the microbial community activity}

After collection of samples, biofilm detachment and inoculation of the EcoPlates, the optical density was measured every 4

15 hours. Once the measurement period (5 days) finalized, the obtained CSUP dataset was processed and subjected to Taylor transformation. After transformation, the CSUP dataset was analyzed using principal component analysis (PCA) (Figure 1). The resulting PCA graph accounts for more than $60 \%$ of the CSUP original information and illustrates the impact of microbial communities inside the 6 tested systems, over the use of 5 different carbon guilds. Figure 1a presents the carbon guilds as main variables of study and the depth level inside the columns as supplementary variables. The carbon guilds amino acids,

20 amides/amines and variable level are related to Factor 1; carbohydrates, carboxylic and acetic acids and polymers are linked to Factor 2. Figure 1b presents the observations and derived centroids from each tested system. Combining the information from both PCA graphs some trends of the microbial populations can be identified, related to the consumption of individual carbon guilds.

The upper part of Figure 1b, groups the planted systems, while non-planted columns are grouped at the lower part. The systems

25 that promote the development of microbial communities tend to consume higher proportion of amino acids and amines/amides, are located on the right-hand side of PCA graph (Sand/P, PK-LSN/P and PK-LSN/NP), whereas the systems located on the left side (Sand/NP, PK-A/NP and PK-LSN/NP), seem to have microbial communities less likely to consume those carbon sources (Figure 1b). The planted systems in the upper part of the PCA graph (Sand/P, PK-A/P and PK-LSN/P) seem to favor the conditions to develop microbial communities inclined to consume carboxylic \& acetic acids in a higher proportion,

30 compared to the non-planted systems (Figure 1b). The consumption of polymers and carbohydrates seem to be higher in proportion for microbial communities associated to the non-planted systems (Sand/NP, PK-A/NP and PK-LSN/NP) in comparison with the planted-ones. The differences between planted and no-planted systems are expected, since the presence 
Biogeosciences Discuss., https://doi.org/10.5194/bg-2018-428

Manuscript under review for journal Biogeosciences

Discussion started: 29 October 2018

(c) Author(s) 2018. CC BY 4.0 License.

of roots provide shelter for biofilm development, as well as allow the release of oxygen and a variety of root exudates that promote the growth microbial communities (Brix, 1997; Lv et al., 2017).

The PCA graph suggests the influence of the level inside the system (in direction of water flow), over the consumption patterns of the microbial communities of the tested systems (Figure 1a). Based on the Pearson correlation matrix, derived from the

5 PCA graphs, it is possible to identify the correlation between the level and the consumption pattern of polymers (0.487), and amino acids (0.306) as a positive middle-strength, the correlation with amines/amides $(0.102)$ as a weak positive, while the correlations of carbohydrates (0.193) and carboxylic \& acetic acids (0.080) as negative weak.

Furthermore, the tested systems were compared based on their CSUP with permutational analysis of variance (PERMANOVA; $p$ < 0.05). The analysis showed two significant different groups of systems: i) Sand/P and PK-LSN/P, ii) Sand/NP and PK-A/NP;

10 whereas the systems PK-A/P and PK-LSN/NP are independent (Figure 2). The similarities among systems in groups i) and ii), are associated to the presence/absence of plants and to the consumption of certain carbon sources by the microbial communities. Except for the case of PK-A/P and PK-LSN/NP system, the separation in groups of planted and non-planted systems is similar to the findings made by Vacca et al., (2005) and Weber et al., (2008), whose results indicate that the microbial communities have similar characteristics in planted systems, but with dissimilarities between non-planted systems.

15 However, in this study also the non-planted systems seem to have similarities between them for the development of microbial communities

The group i) composed by PK-A/NP and PK-LSN/NP, share common microbial activity with a tendency for the consumption of carbohydrates and polymers. The group ii) composed by Sand/P and PK-LSN/P, the microbial community is prone to have a higher consumption of amino acids and amines/amides. In the case of system PK-LSN/NP, the microbial communities tend

20 to consume carbohydrates, amino acids, amides/amines. Whereas the PK-A/P system, seems to promote the conditions for microbial communities predisposed to consume carboxylic \& acetic acids.

\subsection{Microbial community metabolic activity indexes}

The CSUP data set of the tested systems was used to estimate three microbial metabolic activity indexes: AWCD, richness and diversity. The indexes represented the temporal development in a period of 52 hours (Figure $3 \mathrm{a}$, c and e), and for a single

25 time point of 48 hours (Figure $3 \mathrm{~b}, \mathrm{~d}$, and $\mathrm{f}$ ).

The AWCD shows a sigmoid growth pattern along 52 hours in all the tested systems (Figure 3a), indicating that the systems provide suitable conditions for the development of microbial communities. The result patterns coincide with previous CLPP studies of environmental samples (Insam and Goberna, 2004; Weber and Legge, 2010a) and in constructed wetlands (Button et al., 2016a; Salomo et al., 2009). In Sand and PK-LSN systems, the communities show higher metabolic activity compared

30 to the PK-A systems. If a single time point of 48 hours is considered, the AWCD show significant lower values for PK-A systems in comparison to the Sand and PK-LSN systems, but with non-significant differences between them. The growth 
Biogeosciences Discuss., https://doi.org/10.5194/bg-2018-428

Manuscript under review for journal Biogeosciences

Discussion started: 29 October 2018

(c) Author(s) 2018. CC BY 4.0 License.

patterns of richness (sigmoid) and diversity (logarithmic) indexes, show higher values for Sand and PK-LSN systems in comparison with PK-A systems.

The relatively low values of AWCD, richness and diversity in PK-A systems suggests favorable conditions for colonization of electroactive bacteria rather than for more heterogeneous microbial populations. Indications of this can be found in previous

5 studies of microbial characterization of MET for wastewater treatment. Beecroft et al. (2012) reported the colonization of electrodes of a MFC by putative exolectrogenic denitrifiers and sulfate reducers, up to $24 \%$ of the total amount of microbial communities after 91 days of operation. Additionally, Velvizhi et al. (2014) identified changes in the colonization of electrodes in a lab-scale MFC along 278 days of operation (Actinobacteria: from 50\% to 14\%; Proteobacteria: from 17\% to 57\%; Firmicutes: $33 \%$ to 29\%). Yamashita et al. (2015) reported the colonization by Geobacter species (72 \%) of anode electrodes

10 in a lab-scale MFC after 1 month of operation. Aguirre-Sierra et al. (2016) reported a high presence of Deltaproteobacteria in a METland systems with coke biofilters (27\%) and hybrid polarized biofilters $(23 \%)$ in comparison with gravel biofilters (8 \%). J. Wang et al. (2017) reported for a CW-MFC a predominance on the anode material of Proteobacteria ( $\pm 60 \%$ ), and a higher relative abundance between $1 \%$ and $6 \%$ than in unplanted control systems.

Even though no significant differences in AWCD, richness and diversity indexes were found between planted and non-planted

15 systems in the tested systems of each material, the planted systems show higher values than the non-planted. Differences on the microbial community functionality between planted and non-planted systems, studies analyzing the change in microbial community structure in aerated constructed wetlands (Osem et al., 2007) have been reported, treating tannery wastewaters (Calheiros et al., 2009), as well as in full scale constructed wetlands treating domestic wastewaters (Zhang et al., 2010). The differences in microbial activity are influenced by the interaction with plant roots on the rhizosphere zone (Salomo et al.,

20 2009), given that the root systems provide shelter for microbial communities as well as regulating the development by synthetizing, accumulating and releasing root exudates (Weber and Legge, 2009).

\subsection{Effect of vertical profiles on carbon source utilization}

The utilization of the different carbon guilds per tested system, as well as along the flow pathway inside them are shown in Figure 4. The results show a global trend in the use of the available carbon sources, characterized by a high consumption of 25 carbohydrates and carboxylic \& acetic acids, followed in a middle proportion by polymers and amino acids, and in lower proportion by amines/amides. Except for polymers, significant differences in the consumption of carbon guilds can be identified among some systems (Figure 4a). The uniformity in the in carbon guild utilization among the tested systems is similar to the findings reported by Button et al. (2016), except that in their case, the most consumed carbon guild was polymers and the least consumed was amino acids, while in this study, the most consume carbon guild is carbohydrates and the less

30 consumed is amines/amides (Figure 4a).

Following the loading flow path, from bottom $(0 \mathrm{~cm})$ to top $(45 \mathrm{~cm})$, it is possible to identify some differences in terms of the consumption pattern of the carbon guilds. In the case of polymers (Figure 4b), all tested systems show an increase in their consumption as the water level in the systems increases, being the PK-A systems with the highest gradient activity from bottom 
Biogeosciences Discuss., https://doi.org/10.5194/bg-2018-428

Manuscript under review for journal Biogeosciences

Discussion started: 29 October 2018

(c) Author(s) 2018. CC BY 4.0 License.

to top, followed by PK-LSN systems, and in an erratic pattern by the sand filled systems, that shows the highest activity in the middle layers. A similar consumption pattern can be seen for amino acids (Figure 4e) but with oscillations in middle points for some of the tested systems. Regarding carbohydrates, the microbial activity shows a higher consumption gradient from 0 $\mathrm{cm}$ to $45 \mathrm{~cm}$ in Sand/NP, Sand/P and PK-LSN/P systems; for PK-A/NP and PK-LSN/NP, the activity seems to be equal along

5 the flow path, whereas for PK-A/P the highest activity occurs in the uppermost layer $(45 \mathrm{~cm})$ of the system. (Figure $4 \mathrm{c})$. Concerning carboxylic \& acetic acids, there are variations in the consumption along the flow pathway among tested systems. PK-A/NP and PK-LSN/NP show higher consumption in the lowest levels inside the columns in comparison with the upper layer. PK-A/P and PK-LSN/P show similar steady consumption at different levels (except at $25 \mathrm{~cm}$ in PK-A/P), whereas Sand/NP and Sand/P showed higher consumption at $45 \mathrm{~cm}$ in comparison to $0 \mathrm{~cm}$ level, but with variations in the intermediated

10 sampled points. In the case of amines/amides there is a notorious lower consumption in PK-A systems in comparison to Sand and PK-LSN systems. It seems that there are no significant differences among levels inside Sand/P, PK-A and PK-LSN systems. In the Sand/NP system, the highest consumption occurs on the intermediate levels and in a lower proportion without significant differences at 0 and $45 \mathrm{~cm}$ depth.

The results also show that the carbon guild utilization present a mixed pattern of increase/decrease gradients along the flow

15 path, differing from the findings of previous studies. Button et al. (2015) found decreasing gradients between inlet and outlet in the consumption of carbon guilds, with the steepest gradients in carbohydrates, polymers and amines/amides and with smooth gradients for amino acids and carboxylic acids. Similar pattern was found by Button et al. (2016) that reported the utilization of all carbon source, being higher at inlet sections than in the outlet section in CWs working in series.

Easy degradable carbon sources, such as carbohydrates are preferred by microorganism as primary source of energy, and

20 usually are consume at early stages of the flow pathway inside systems (Salomo et al., 2009). In this study, the consumption gradients of carbohydrates and carboxylic \& acetic acid, indicates that these are easily metabolized by microbial communities at earliest stages of the flow. In the case of polymers, it the opposite occurred, with relative low consumption in the inlet section and higher consumption at the outlet section of the tested systems. Excepting for carbohydrates, the reported carbon guild consumption patterns are opposite to the findings made by Button et al. (2015) which identified a high utilization of 25 polymers, carbohydrates and amines/amides at early stages in tested constructed wetland systems. Truu et al. (2009) stated that the hydraulic conditions have an impact on the structure, spatial distribution and activity of microbial communities, therefore the differences in carbon guild consumption in this study, compared to the results of previous studies, could be related to the up-flow operation of the systems, rather than the media nor if the systems were planted or not.

\subsection{Effluent water quality and correlation with microbial metabolic indexes}

30 In parallel to the microbial metabolic activity, were measured the effluent water quality parameters ( $\mathrm{pH}$, electrical conductivity, temperature, dissolved oxygen and Redox potential), and were estimated the removal rates of organic matter ( $\mathrm{BOD}_{5}, \mathrm{TOC}_{\text {and }}$ $\mathrm{COD}$ ), nutrients $\left(\mathrm{NO}_{3}-\mathrm{N}, \mathrm{NH}_{4}-\mathrm{N}, \mathrm{TN}\right.$ and $\left.\mathrm{PO}_{4}-\mathrm{P}\right)$ and TSS (Table 3). Regarding water quality parameters, no significant differences among the tested systems were evident. $\mathrm{pH}$ values ranged between 7.9 and 8.0 units, electrical conductivity varied 
Biogeosciences Discuss., https://doi.org/10.5194/bg-2018-428

Manuscript under review for journal Biogeosciences

Discussion started: 29 October 2018

(c) Author(s) 2018. CC BY 4.0 License.

0.8 and $0.9 \mathrm{mS} \mathrm{cm}^{-1}$, water temperature ranged between 16.5 to $17.4{ }^{\circ} \mathrm{C}$, dissolved oxygen varied between 3.7 and $4.9 \mathrm{mg} \mathrm{L}^{-1}$, and Redox potential between 212 and $233 \mathrm{mV}$.

The composition of the wastewater at inlet has a BOD/COD ratio of 0.78 , which denotes a wastewater with organic content relatively easy to degrade by biological-based systems (Metcalf \& Eddy Inc., 2004). Therefore, the removal of $\mathrm{BOD}_{5}$ in all

5 systems was above $85 \%$. The removal efficiencies of the electro-conductive systems (PK-A and PK-LSN) are expected to be comparable to the removal efficiencies reported by Aguirre-Sierra et al. (2016), where in a METland system reached removals of up to $93 \%$. Regarding COD removal, the electro-conductive material filled systems reached efficiencies above $80 \%$, whereas for Sand systems, the removal efficiency was around 76\%. PK-A/NP system reached removal rates as high as $88 \%$. Even though there were no significant differences between planted and non-planted systems, the results show slightly higher 10 removal efficiency in non-planted systems. The findings differ of those from Saz et al. (2018), where in a CW-MFC, planted systems showed better performance than non-planted systems, reaching COD removal rates between $85 \%$ to $88 \%$. The removal efficiencies of PK-A and PK-LSN systems are comparable to values reported by Fang et al. (2017), where CW-MFC was able to remove COD loads of $90 \%$, or with the values reported for a CW-MFC with assisted aeration with removal efficiencies above $82 \%$ (Xu et al., 2018a). TOC removal efficiencies ranged between 77 and $79 \%$.

15 Regarding nutrients, the removal of $\mathrm{NH}_{4}-\mathrm{N}$ ranged between 17 and $28 \%$, without significant differences among the tested systems, but with higher values in PK-A and PK-LSN systems in comparison to the Sand systems, as well as with higher values for the planted systems. The low $\mathrm{NH}_{4}-\mathrm{N}$ removal efficiencies in the tested systems are explained by their operation mode as water saturated system that limits the diffusion of $\mathrm{O}_{2}$ in the systems resulting in low dissolved oxygen concentration to fuel nitrification. The difference between planted and non-planted systems, suggests that vegetation has an impact on the

20 removal of $\mathrm{NH}_{4}-\mathrm{N}$ in tested systems, as it is reported in conventional CW (Brix, 1997; Vymazal, 2010). NH4-N removal efficiency in the current test is comparable to the removal reported in horizontal flow constructed wetlands (between $20 \%$ and $30 \%$ ), but lower than vertical flow constructed wetlands (> 90\%) (Dotro et al., 2017). $\mathrm{NH}_{4}-\mathrm{N}$ removal efficiencies are lower when compared to other microbial electrochemical-based systems such as in assisted aeration a CW-MFC which according to Oon et al. (2016) reached removal efficiencies of $96 \%$, or as reported for air cathode CW-MFC amended with dewatered alum

25 sludge with removal rates between $58 \%$ and $81 \%$ (L. Xu et al., 2018), or as reported by Saz et al. (2018) reaching removal efficiencies above $95 \%$ in an upflow CW-MFC.

The highest removal efficiency of $\mathrm{NO}_{3}-\mathrm{N}$ was reached in sand systems (19 to $40 \%$ ) followed by PK-LSN (from 21 to $23 \%$ ) and PK-A systems (from 13 to 17\%). The $\mathrm{NO}_{3}-\mathrm{N}$ removal efficiencies are lower in comparison with other CW-MFC, like reported by Wang et al. (2016) reaching $80 \%$ removal with a system using carbon felt electrodes, or those reported by Yakar

30 et al. (2018) where with an upflow CW-MFC, using zeolite as filter media removed up to $81 \%$, or as reported by (J. Wang et al., 2017) reaching removal efficiencies around $87 \%$.

Given that the main removal pathway of $\mathrm{NO}_{3}-\mathrm{N}$ is denitrification a carbon source is required (Dotro et al., 2017), therefore the low removal efficiencies could be explained by the relatively low $\mathrm{BOD}_{5}$ remaining in the systems as it is treated along the flow. The tested systems reached TN removal rates between 46 and $50 \%$, without significant differences among them; the 
Biogeosciences Discuss., https://doi.org/10.5194/bg-2018-428

Manuscript under review for journal Biogeosciences

Discussion started: 29 October 2018

(c) Author(s) 2018. CC BY 4.0 License.

removal of TN is similar to horizontal flow constructed wetlands and lower than vertical flow constructed wetlands (Dotro et al., 2017) (Kadlec and Wallace, 2009). The removal efficiencies are comparable with results reported by (L. Xu et al., 2016) but lower than $82 \%$ removal efficiency reported by (Xu et al., 2018a). The low TN removal is the results of the operation of tested systems under saturated regime, which given the anoxic conditions, the nitrification process is limited by the lack of $\mathrm{O}_{2}$;

5 whereas the denitrification process could be limited by low amounts of organic matter and nitrate available in the systems (Dotro et al., 2017).

The average removal percentage of $\mathrm{PO}_{4}-\mathrm{P}$ ranged between 88 and 96\% in Sand systems, which is higher than in PK-A systems $( \pm 79 \%$ ) and PK-LSN systems (45 to $47 \%$ ). The highest performance in sand and PK-LSN columns could be the associated effect of filtration and precipitation processes (Dotro et al., 2017). The highest performance of PK-A systems in comparison

10 with PK-LSN systems, could be a consequence of adsorption processes, given that the PK-A material contain iron traces that are manifested by the formation of iron oxide patches on the surface of the materials, as well as by the reddish color of the material at the effluent section of the columns. The presence of iron oxide is known to aid the adsorption phosphorous on the surface of materials (Kadlec and Wallace, 2009). PO4-P removal in PK-A systems could be comparable with removal efficiency reported for CW-MFC amended with dewatered alum sludge (94\%) (Xu et al., 2017), or with the removal efficiency

15 of $74 \%$ reached in a electrolysis-based horizontal flow constructed wetland reported by Gao et al. (2018).

As for TSS removal, the best removal was obtained by the electro-conductive material PK-LSN, with removal rates between 87 and $90 \%$ followed by Sand systems between 81 and $84 \%$ and PK-A systems with removals between 82 and $85 \%$. The high performance of PK-LSN systems might be associated to the highest porosity of the material (55\%; Table 1) therefore with higher filtration capacity.

20 In parallel to the water quality analysis, correlation analysis of the microbial metabolic activity indexes, the carbon guild utilization and the removal efficiency of organic matter (BOD5, COD and TOC) and nitrogen ( $\mathrm{NO}_{3}-\mathrm{N}$ and $\left.\mathrm{TN}\right)$ for the tested systems, was done based on a PCA correlation biplot (Figure 5). The analysis excluded NH4-N (which is mediated by nitrifying bacteria), $\mathrm{PO}_{4}-\mathrm{P}$ and TSS (whose removal mechanism are related to the physical-chemical processes of filtration, adsorption and precipitation). In general, the systems located on the right side of the correlation biplot (PK-LSN/P, PK-LSN/NP and

$25 \mathrm{Sand} / \mathrm{P}$ ) have higher values of AWCD, diversity and richness, indicating that these systems present more heterogeneous microbial communities, compared to those located on the left side (PK-A/P, PK-A/NP and Sand/NP), which seems to have more homogeneous microbial communities.

The Sand/P, PK-LSN/P and PK-LSN/NP systems seem to promote the conditions for microbial activity prone to consume amines/amides and amino acids. Additionally, in the case of PK-LSN/P and Sand/P systems, their metabolic activity also tents

30 to consume carboxylic \& acetic acids, whereas in PK-LSN/NP system, the microbial communities are inclined to consume polymers (Figure 5). The carbon guild consumption pattern of Sand/P, PK-LSN/P and PK-LSN/NP seem to be strongly related with the removal of $\mathrm{NO}_{3}-\mathrm{N}$, suggesting the involvement of microbial communities that consume the carbon guilds in denitrification process, in contrast with the impact consumption patterns have on the removal of COD and TN. 
Biogeosciences Discuss., https://doi.org/10.5194/bg-2018-428

Manuscript under review for journal Biogeosciences

Discussion started: 29 October 2018

(c) Author(s) 2018. CC BY 4.0 License.

In general, the non-planted systems showed microbial communities prone to consume in a higher extend polymers which seems to be related to the removal of $\mathrm{BOD}_{5}$ and $\mathrm{TOC}$. $\mathrm{BOD}_{5}$ show a negative correlation with the consumption of carboxylic and acetic acids, and TOC with amines/amides, amino acids and carboxylic and acetic acids. In the case of PK-LSN/NP system, besides having carbon guild consumption patterns related with the removal of $\mathrm{NO}_{3}-\mathrm{N}$ removal, the activity of the microbial

5 community, related in the consumption of polymers, also is involved in a high extend in $\mathrm{BOD}_{5}$ and in $\mathrm{TOC}$ removal. Likewise, the microbial communities on non-planted systems seems to have a relative lower impact on the removal of $\mathrm{NH}_{4}-\mathrm{N}$, in comparison with planted ones (Figure 5). However, is important to highlight that for TN removal efficiencies, apart of being related with $\mathrm{NO}_{3}-\mathrm{N}$ removal, also is related with nitrification processes and plant uptake.

The systems located on the left side of the correlation biplot, seem to have more homogeneous microbial communities than

10 those located on the right side, therefore having different carbon guild consumption preferences (Figure 5). This difference could be associated to the absence of plants in Sand/NP and PK-A/NP, given that usually planted systems have higher microbial diversity than non-planted (Salomo et al., 2009; Weber \& Legge, 2009), and by the electroconductive characteristics of the material in PK-A systems, that has an impact on the richness and diversity of microbial communities (Figure 3). For instance, the microbial communities in Sand/NP systems are prone to consume polymers in a higher extend and carbohydrates which

15 seems to be related to a high extend to the removal of $\mathrm{BOD}_{5}$ and TOC. Likewise, PK-A/NP system possess microbial communities that consume polymers which could to be related with the removal of $\mathrm{BOD}_{5}$ and TOC, and carbohydrates, which seems to be related to the removal of COD as well as TOC. Whereas in the case of PK-A/P, it has a high higher consumption of carboxylic \& acetic acids and carbohydrates, which seems to be related to the removal of COD.

Despite that, the PK-A systems still have microbial communities that contribute to the removal of COD and TN (through

20 nitrification-denitrification processes), the highest COD removal rates are reached by these systems, therefore should exist a relation between the characteristics of the material that become selective to the creation of microbial biofilms that ease the consumption of COD and TN.

\section{Conclusions}

To the best of our knowledge there are no publications reporting the microbial metabolic activity function in electroactive

25 biofilm-based constructed wetlands. The assessment of the microbial metabolic activity was done in a fast and easy way based on CLPP analysis and with the use of BIOLOG ${ }^{\mathrm{TM}}$ EcoPlates. In the present study were identified differences in terms of the metabolic activity of systems using electro-conductive materials in comparison with control systems.

PK-A systems show lower values of AWCD, richness and diversity, in comparison with Sand and PK-LSN systems. This could constitute as an indicator of the impact of the material in the evolution of the microbial metabolic activity inside 30 electroconductive the systems. This means that the electro-conductive properties of PK-A system, provides favorable conditions for the development of more homogeneous microbial biofilms, similarly to previous studies were carbon-based 
Biogeosciences Discuss., https://doi.org/10.5194/bg-2018-428

Manuscript under review for journal Biogeosciences

Discussion started: 29 October 2018

(c) Author(s) 2018. CC BY 4.0 License.

electrodes operating for certain long periods, have been reported changes in the microbial communities attached to the electrodes (Aguirre-Sierra et al.,2016; J. Wang et al., 2017).

Judging by the values of AWCD, richness and diversity, the planted systems have a slight impact on the microbial metabolic activity of tested systems, however, the registered differences are not significant between planted and non-planted system. The carbon guild utilization showed a general trend in all tested systems, with a high consumption of carbohydrates and carboxylic and acetic acids, followed in a middle proportion by polymers and amino acids, and in lower proportion by amines and amides. Also, the carbon guild utilization shows differences along the flow path in the systems, as well as among them.

The trends in the consumption of carbon guilds, have an impact on the values of microbial metabolic indexes. The systems with relatively higher consumption of amino acids, amines/amides and polymers (PK-LSN/P, PK-LSN/NP and Sand/NP)

10 seems to have more heterogeneous microbial communities in comparison with those systems with a relatively high consumption of carboxylic and acetic acids and carbohydrates (PK-A/P, PK-A/NP and Sand/P).

The consumption of carbon guilds is associated with the removal efficiency of the testes systems. $\mathrm{NO}_{3}-\mathrm{N}$ removal is associated to the consumption of amines/amides, amino acids, and polymers, which according to the profiles of the systems, are consumed at higher rates in the outlet section of the systems, indicating that denitrification processes is taking place. The microbial 15 communities likely to consume polymers, are involved in a high extend in the removal of $\mathrm{BOD}_{5}$ and TOC. Whereas the microbial communities prone to consume carbohydrates, which occur in a higher proportion at the inlet zones of the systems, are involved in the removal of COD as well as TOC.

\section{Author Contributions}

Conceptualization, C.R., C.A.; investigation, C.R.; formal analysis, C.R., L.Z (supporting); supervision, C.A., H.B.; writingoriginal draft, C.R.; writing-review \& editing, C.A, L.Z., H.B.

\section{Competing interests}

The authors declare that they have no conflict of interest.

\section{Acknowledgements}

This study was supported with resources of the project "iMETland: A new generation of Microbial Electrochemical Wetland

25 for effective decentralized wastewater treatment systems", funded by European Union's Horizon 2020 research and innovation programme (grant agreement No. 642190). Carlos A. Ramirez-Vargas kindly acknowledges to the Administrative Department of Science and Technology of Colombia (COLCIENCIAS) for granting his PhD scholarship (conv. 646/2014). Special thanks 
Biogeosciences Discuss., https://doi.org/10.5194/bg-2018-428

Manuscript under review for journal Biogeosciences

Discussion started: 29 October 2018

(c) Author(s) 2018. CC BY 4.0 License.

to Lone J. Ottosen and Mads Elkjær Tønnes (Dept. of Bioscience - Aquatic Biology, Aarhus University) for their invaluable support in field work and laboratory analysis.

\section{References}

Adrados, B., Sánchez, O., Arias, C. A., Becares, E., Garrido, L., Mas, J., Brix, H. and Morató, J.: Microbial communities from different types of natural wastewater treatment systems: Vertical and horizontal flow constructed wetlands and biofilters, Water Res., 55, 304-312, doi:10.1016/J.WATRES.2014.02.011, 2014.

Aguirre-Sierra, A., Bacchetti De Gregoris, T., Berná, A., Salas, J. J., Aragón, C. and Esteve-Núñez, A.: Microbial Electrochemical Systems outperform fixed-bed biofilters for cleaning-up urban wastewater, Environ. Sci. Water Res. Technol., 2, 4435-4448, doi:10.1039/c1ee01745d, 2016.

10 Beecroft, N. J., Zhao, F., Varcoe, J. R., Slade, R. C. T., Thumser, A. E. and Avignone-Rossa, C.: Dynamic changes in the microbial community composition in microbial fuel cells fed with sucrose, Appl. Microbiol. Biotechnol., 93(1), 423-437, doi:10.1007/s00253-011-3590-y, 2012.

Borole, A. P., Reguera, G., Ringeisen, B., Wang, Z.-W., Feng, Y. and Kim, B. H.: Electroactive biofilms: Current status and future research needs, Energy Environ. Sci., 4(12), 4813, doi:10.1039/c1ee02511b, 2011.

15 Brix, H.: Do macrophytes play a role in constructed treatment wetlands?, Water Sci. Technol., 35(5), 11-17, doi:10.1016/S0273-1223(97)00047-4, 1997.

Brix, H., Koottatep, T. and Laugesen, C. H.: Wastewater treatment in tsunami affected areas of Thailand by constructed wetlands., 2007.

Butti, S. K., Velvizhi, G., Sulonen, M. L. K., Haavisto, J. M., Oguz Koroglu, E., Yusuf Cetinkaya, A., Singh, S., Arya, D.,

20 Annie Modestra, J., Vamsi Krishna, K., Verma, A., Ozkaya, B., Lakaniemi, A.-M., Puhakka, J. A. and Venkata Mohan, S.: Microbial electrochemical technologies with the perspective of harnessing bioenergy: Maneuvering towards upscaling, Renew. Sustain. Energy Rev., 53, 462-476, doi:10.1016/j.rser.2015.08.058, 2016.

Button, M., Nivala, J., Weber, K. P., Aubron, T. and Müller, R. A.: Microbial community metabolic function in subsurface flow constructed wetlands of different designs, Ecol. Eng., 80, 162-171, doi:10.1016/j.ecoleng.2014.09.073, 2015.

25 Button, M., Weber, K., Nivala, J., Aubron, T. and Müller, R. A.: Community-Level Physiological Profiling of Microbial Communities in Constructed Wetlands: Effects of Sample Preparation, Appl. Biochem. Biotechnol., 178(5), 960-973, doi:10.1007/s12010-015-1921-7, 2016a.

Button, M., Rodriguez, M., Brisson, J. and Weber, K. P.: Use of two spatially separated plant species alters microbial community function in horizontal subsurface flow constructed wetlands, Ecol. Eng., 92, 18-27, 30 doi:10.1016/J.ECOLENG.2016.03.044, 2016b.

Calheiros, C. S. C., Duque, A. F., Moura, A., Henriques, I. S., Correia, A., Rangel, A. O. S. S. and Castro, P. M. L.: Changes in the bacterial community structure in two-stage constructed wetlands with different plants for industrial wastewater 
Biogeosciences Discuss., https://doi.org/10.5194/bg-2018-428

Manuscript under review for journal Biogeosciences

Discussion started: 29 October 2018

(c) Author(s) 2018. CC BY 4.0 License.

treatment, Bioresour. Technol., 100(13), 3228-3235, doi:10.1016/J.BIORTECH.2009.02.033, 2009.

Doherty, L., Zhao, Y., Zhao, X., Hu, Y., Hao, X., Xu, L. and Liu, R.: A review of a recently emerged technology: Constructed wetland - microbial fuel cells, Water Res., doi:10.1016/j.watres.2015.08.016, 2015.

Dotro, G., Molle, P., Nivala, J., Puigagut, J. and Stein, O.: Treatment Wetlands, First., IWA Publishing, London., 2017.

5 Escapa, A., San-Martín, M. I. and Morán, A.: Potential Use of Microbial Electrolysis Cells in Domestic Wastewater Treatment Plants for Energy Recovery, Front. Energy Res., 2(June), 1-10, doi:10.3389/fenrg.2014.00019, 2014.

Esteve-Núñez, A.: Electricity-generating bacteria Bioelectrogenesis : sustainable biotechnology, Int. Innov., 181, 109-111, 2015.

Fang, Z., Cheng, S., Cao, X., Wang, H. and Li, X.: Effects of electrode gap and wastewater condition on the performance of 10 microbial fuel cell coupled constructed wetland, Environ. Technol. (United Kingdom), 38(8), 1051-1060, doi:10.1080/09593330.2016.1217280, 2017.

Faulwetter, J. L., Gagnon, V., Sundberg, C., Chazarenc, F., Burr, M. D., Brisson, J., Camper, A. K. and Stein, O. R.: Microbial processes influencing performance of treatment wetlands: A review, Ecol. Eng., 35(6), 987-1004, doi:10.1016/J.ECOLENG.2008.12.030, 2009.

15 Gao, C., Wang, A., Wu, W.-M., Yin, Y. and Zhao, Y.-G.: Enrichment of anodic biofilm inoculated with anaerobic or aerobic sludge in single chambered air-cathode microbial fuel cells., Bioresour. Technol., 167, 124-32, doi:10.1016/j.biortech.2014.05.120, 2014.

Gao, Y., Zhang, W., Gao, B., Jia, W., Miao, A., Xiao, L. and Yang, L.: Highly efficient removal of nitrogen and phosphorus in an electrolysis-integrated horizontal subsurface-flow constructed wetland amended with biochar, Water Res., 139, 301-310,

20 doi:10.1016/J.WATRES.2018.04.007, 2018.

Garland, J. L.: Analysis and interpretation of community-level physiological profiles in microbial ecology, FEMS Microbiol. Ecol., 24(4), 289-300, doi:10.1016/S0168-6496(97)00061-5, 1997.

Garland, J. L. and Mills, A. L.: Classification and characterisation of heterotrophic microbial communities on the basis of pattern of community-level sole-carbon-source utilization, Appl. Environ. Microbiol., 57(8), 2351-2359, doi:00992240/91/082351-09\$02.00/0, 1991.

Ghobrial, M. G.: Pigments and Moisture Contents in Phragmites australis ( Cav .) Trin . Ex Steudel, Would Be Engines for Monitoring Biodegradation of Petroleum Contaminants in Constructed Wetlands, Aust. J. Basic Appl. Sci., 2(4), 1068-1075, 2008 .

Hammer, Ø., Harper, D. A. T. a. T. and Ryan, P. D.: PAST: Paleontological Statistics Software Package for Education and 30 Data Analysis, Palaeontol. Electron., 4(1)(1), 1-9, doi:10.1016/j.bcp.2008.05.025, 2001.

Insam, H. and Goberna, M.: Use of Biolog for the Community Level Physiological Profiling ( CLPP ) of environmental samples, in Molecular Microbial Ecology Manual, edited by G. A. Kowalchuk, F. de Brujin, A. J. Van der Zijpp, and J. D. van Elsas, pp. 853-860, Springer Netherlands., 2004.

Kadlec, R. and Wallace, S.: Treatment wetlands, Second., edited by C. Press, CRC Press, Boca Raton, FL., 2009. 
Biogeosciences Discuss., https://doi.org/10.5194/bg-2018-428

Manuscript under review for journal Biogeosciences

Discussion started: 29 October 2018

(c) Author(s) 2018. CC BY 4.0 License.

Langergraber, G. and Masi, F.: Treatment wetlands in decentralised approaches for linking sanitation to energy and food security, Water Sci. Technol., 77(4), 859-860, doi:10.2166/wst.2017.599, 2018.

Li, T., Fang, Z., Yu, R., Cao, X., Song, H. and Li, X.: The performance of the microbial fuel cell-coupled constructed wetland system and the influence of the anode bacterial community, Environ. Technol. (United Kingdom), 37(13), 1683-1692, doi:10.1080/09593330.2015.1127292, 2016.

Lobato, J., Cañizares, P., Fernández, F. J. and Rodrigo, M. A.: An evaluation of aerobic and anaerobic sludges as start-up material for microbial fuel cell systems., N. Biotechnol., 29(3), 415-20, doi:10.1016/j.nbt.2011.09.004, 2012.

Logan, B. E.: Exoelectrogenic bacteria that power microbial fuel cells, Nat. Rev. Microbiol., 7(May 2009), 375-381, doi:10.1038/nrmicro2113, 2009.

10 Lovley, D. R.: Extracellular electron transfer: Wires, capacitors, iron lungs, and more, Geobiology, 6(3), 225-231, doi:10.1111/j.1472-4669.2008.00148.x, 2008.

Lv, T., Carvalho, P. N., Zhang, L., Zhang, Y., Button, M., Arias, C. A., Weber, K. P. and Brix, H.: Functionality of microbial communities in constructed wetlands used for pesticide remediation: Influence of system design and sampling strategy, Water Res., 110, 241-251, doi:10.1016/J.WATRES.2016.12.021, 2017.

15 Masi, F., Rizzo, A. and Regelsberger, M.: The role of constructed wetlands in a new circular economy, resource oriented, and ecosystem services paradigm, J. Environ. Manage., 216, 275-284, doi:10.1016/J.JENVMAN.2017.11.086, 2018.

Metcalf \& Eddy Inc.: Wastewater Engineering: Treatment and Reuse, Fourt., edited by G. Tchobanoglous, F. L. Burton, and H. D. Stensel, McGraw-Hill, New York., 2004.

Min, B., Kim, J., Oh, S., Regan, J. M. and Logan, B. E.: Electricity generation from swine wastewater using microbial fuel

20 cells., Water Res., 39(20), 4961-8, doi:10.1016/j.watres.2005.09.039, 2005.

Nivala, J., Wallace, S., Headley, T., Kassa, K., Brix, H., van Afferden, M. and Müller, R.: Oxygen transfer and consumption in subsurface flow treatment wetlands, Ecol. Eng., 61(August 2012), 544-554, doi:10.1016/j.ecoleng.2012.08.028, 2012.

Oon, Y.-L., Ong, S.-A., Ho, L.-N., Wong, Y.-S., Dahalan, F. A., Oon, Y.-S., Lehl, H. K. and Thung, W.-E.: Synergistic effect of up-flow constructed wetland and microbial fuel cell for simultaneous wastewater treatment and energy recovery, Bioresour.

25 Technol., 203, 190-197, doi:10.1016/j.biortech.2015.12.011, 2016.

Osem, Y., Chen, Y., Levinson, D. and Hadar, Y.: The effects of plant roots on microbial community structure in aerated wastewater-treatment reactors, Ecol. Eng., 29(2), 133-142, doi:10.1016/J.ECOLENG.2006.06.003, 2007.

Paredes, D., Vélez, M. E., Kuschk, P. and Mueller, R. A.: Effects of type of flow, plants and addition of organic carbon in the removal of zinc and chromium in small-scale model wetlands, Water Sci. Technol., 56(3), 199 LP-205 [online] Available

30 from: http://wst.iwaponline.com/content/56/3/199.abstract, 2007.

Ramirez-Vargas, C. A., Prado, A., Arias, C. A., Carvalho, P. N., Esteve-Núñez, A. and Brix, H.: Microbial electrochemical technologies for wastewater treatment: principles and evolution from microbial fuel cells to bioelectrochemical-based constructed wetlands, Water, 10(9), 1-29, doi:https://doi.org/10.3390/w10091128, 2018.

Reed, S. C., Crites, R. W. and Middlebrooks, E. J.: Natural Systems for Waste Management and Treatment, 2nd editio., 
Biogeosciences Discuss., https://doi.org/10.5194/bg-2018-428

Manuscript under review for journal Biogeosciences

Discussion started: 29 October 2018

(c) Author(s) 2018. CC BY 4.0 License.

McGraw-Hill, Inc., USA., 1995.

Risgaard-Petersen, N., Damgaard, L. R., Revil, A. and Nielsen, L. P.: Mapping electron sources and sinks in a marine biogeobattery, J. Geophys. Res. G Biogeosciences, 119(8), 1475-1486, doi:10.1002/2014JG002673, 2014.

Sajana, T. K., Ghangrekar, M. M. and Mitra, A.: Application of sediment microbial fuel cell for in situ reclamation of

5 aquaculture pond water quality, Aquac. Eng., 57, 101-107, doi:10.1016/j.aquaeng.2013.09.002, 2013.

Salomo, S., Münch, C. and Röske, I.: Evaluation of the metabolic diversity of microbial communities in four different filter layers of a constructed wetland with vertical flow by Biolog ${ }^{\mathrm{TM}}$ analysis, Water Res., 43(18), 4569-4578, doi:10.1016/J.WATRES.2009.08.009, 2009.

Saz, Ç., Türe, C., Türker, O. C. and Yakar, A.: Effect of vegetation type on treatment performance and bioelectric production

10 of constructed wetland modules combined with microbial fuel cell ( CW-MFC ) treating synthetic wastewater, Environ. Sci. Pollut. Res., 25, 8777-8792, 2018.

Schröder, U., Harnisch, F. and Angenent, L. T.: Microbial electrochemistry and technology: terminology and classification, Energy Environ. Sci., 8(2), 513-519, doi:10.1039/C4EE03359K, 2015.

Truu, M., Juhanson, J. and Truu, J.: Microbial biomass, activity and community composition in constructed wetlands, Sci.

15 Total Environ., 407(13), 3958-3971, doi:10.1016/J.SCITOTENV.2008.11.036, 2009.

Vacca, G., Wand, H., Nikolausz, M., Kuschk, P. and Kästner, M.: Effect of plants and filter materials on bacteria removal in pilot-scale constructed wetlands, Water Res., 39(7), 1361-1373, doi:10.1016/J.WATRES.2005.01.005, 2005.

Velvizhi, G. and Venkata Mohan, S.: Bioelectrogenic role of anoxic microbial anode in the treatment of chemical wastewater: Microbial dynamics with bioelectro-characterization, Water Res., 70, 52-63, doi:10.1016/j.watres.2014.11.002, 2015.

20 Velvizhi, G., Goud, R. K. and Venkata Mohan, S.: Anoxic bio-electrochemical system for treatment of complex chemical wastewater with simultaneous bioelectricity generation, Bioresour. Technol., 151, 214-220, doi:10.1016/j.biortech.2013.10.028, 2014.

Vilajeliu-Pons, A., Puig, S., Pous, N., Salcedo-Dávila, I., Bañeras, L., Balaguer, M. D. and Colprim, J.: Microbiome characterization of MFCs used for the treatment of swine manure., J. Hazard. Mater., 288, 60-8, doi:10.1016/j.jhazmat.2015.02.014, 2015.

Villano, M., Aulenta, F., Beccari, M. and Majone, M.: Start-up and performance of an activated sludge bioanode in microbial electrolysis cells, Chem. Eng. Trans., 27, 109-114, doi:10.3303/CET1227019, 2012.

Vymazal, J.: The use constructed wetlands with horizontal sub-surface flow for various types of wastewater, Ecol. Eng., 35(1), 1-17, doi:10.1016/j.ecoleng.2008.08.016, 2009.

30 Vymazal, J.: Constructed Wetlands for Wastewater Treatment, Water, 2(3), 530-549, doi:10.3390/w2030530, 2010.

Vymazal, J.: Constructed wetlands for treatment of industrial wastewaters: A review, Ecol. Eng., 73, 724-751, doi:10.1016/j.ecoleng.2014.09.034, 2014.

Wang, J., Song, X., Wang, Y., Abayneh, B., Li, Y., Yan, D. and Bai, J.: Nitrate removal and bioenergy production in constructed wetland coupled with microbial fuel cell: Establishment of electrochemically active bacteria community on anode, 
Biogeosciences Discuss., https://doi.org/10.5194/bg-2018-428

Manuscript under review for journal Biogeosciences

Discussion started: 29 October 2018

(c) Author(s) 2018. CC BY 4.0 License.

Bioresour. Technol., 221, 358-365, doi:10.1016/j.biortech.2016.09.054, 2016.

Wang, J., Song, X., Wang, Y., Bai, J., Bai, H., Yan, D., Cao, Y., Li, Y., Yu, Z. and Dong, G.: Bioelectricity generation, contaminant removal and bacterial community distribution as affected by substrate material size and aquatic macrophyte in constructed wetland-microbial fuel cell, Bioresour. Technol., 245(August), 372-378, doi:10.1016/j.biortech.2017.08.191, $52017 \mathrm{a}$.

Wang, J., Song, X., Wang, Y., Bai, J., Li, M., Dong, G., Lin, F., Lv, Y. and Yan, D.: Bioenergy generation and rhizodegradation as affected by microbial community distribution in a coupled constructed wetland-microbial fuel cell system associated with three macrophytes, Sci. Total Environ., 607-608, 53-62, doi:10.1016/J.SCITOTENV.2017.06.243, 2017b.

Wang, Y., Zhao, Y., Xu, L., Wang, W., Doherty, L., Tang, C., Ren, B. and Zhao, J.: Constructed wetland integrated microbial fuel cell system: looking back, moving forward, Water Sci. Technol., 76(2), 471-477, doi:10.2166/wst.2017.190, 2017c.

Weber, K. P. and Gagnon, V.: Microbiology in Treatment Wetlands, Sust Sanit Pr., (18), 25-30, 2014.

Weber, K. P. and Legge, R. L.: One-dimensional metric for tracking bacterial community divergence using sole carbon source utilization patterns, J. Microbiol. Methods, 79(1), 55-61, doi:10.1016/J.MIMET.2009.07.020, 2009.

Weber, K. P. and Legge, R. L.: Community level physiological profiling, in Methods in Molecular Biology: Bioremediation, vol. 599, edited by S. P. Cummings, pp. 263-281, The Humana Press Inc., New Jersey., $2010 \mathrm{a}$.

Weber, K. P. and Legge, R. L.: Method for the detachment of culturable bacteria from wetland gravel, J. Microbiol. Methods, 80(3), 242-250, doi:10.1016/J.MIMET.2010.01.006, 2010b.

Weber, K. P., Grove, J. A., Gehder, M., Anderson, W. A. and Legge, R. L.: Data transformations in the analysis of communitylevel substrate utilization data from microplates, J. Microbiol. Methods, 69(3), 461-469, doi:10.1016/J.MIMET.2007.02.013, 2007.

Weber, K. P., Gehder, M. and Legge, R. L.: Assessment of changes in the microbial community of constructed wetland mesocosms in response to acid mine drainage exposure, Water Res., 42(1-2), 180-188, doi:10.1016/J.WATRES.2007.06.055, 2008.

Wu, H., Zhang, J., Ngo, H. H., Guo, W., Hu, Z., Liang, S., Fan, J. and Liu, H.: A review on the sustainability of constructed

25 wetlands for wastewater treatment: Design and operation., Bioresour. Technol., 175C, 594-601, doi:10.1016/j.biortech.2014.10.068, 2014a.

Wu, S., Kuschk, P., Brix, H., Vymazal, J. and Dong, R.: Development of constructed wetlands in performance intensifications for wastewater treatment: a nitrogen and organic matter targeted review., Water Res., 57, 40-55, doi:10.1016/j.watres.2014.03.020, 2014b.

30 Xu, F., Cao, F., Kong, Q., Zhou, L., Yuan, Q., Zhu, Y., Wang, Q., Du, Y. and Wang, Z.: Electricity production and evolution of microbial community in the constructed wetland-microbial fuel cell, Chem. Eng. J., 339, 479-486, doi:10.1016/J.CEJ.2018.02.003, 2018a.

Xu, L., Zhao, Y., Doherty, L., Hu, Y. and Hao, X.: Promoting the bio-cathode formation of a constructed wetland-microbial fuel cell by using powder activated carbon modified alum sludge in anode chamber, Sci. Rep., 6(February), 1-9, 
Biogeosciences Discuss., https://doi.org/10.5194/bg-2018-428

Manuscript under review for journal Biogeosciences

Discussion started: 29 October 2018

(c) Author(s) 2018. CC BY 4.0 License.

doi:10.1038/srep26514, 2016.

Xu, L., Zhao, Y., Wang, T., Liu, R. and Gao, F.: Energy capture and nutrients removal enhancement through a stacked constructed wetland incorporated with microbial fuel cell, Water Sci. Technol., 76(1), doi:10.2166/wst.2017.168, 2017.

Xu, L., Zhao, Y., Wang, X. and Yu, W.: Applying multiple bio-cathodes in constructed wetland-microbial fuel cell for

5 promoting energy production and bioelectrical derived nitrification-denitrification process, Chem. Eng. J., 344, 105-113, doi:10.1016/J.CEJ.2018.03.065, 2018b.

Yadav, A. K., Dash, P., Mohanty, A., Abbassi, R. and Mishra, B. K.: Performance assessment of innovative constructed wetland-microbial fuel cell for electricity production and dye removal, Ecol. Eng., 47, 126-131, doi:10.1016/j.ecoleng.2012.06.029, 2012.

10 Yakar, A., Türe, C., Türker, O. C., Vymazal, J. and Saz, Ç.: Impacts of various filtration media on wastewater treatment and bioelectric production in up-flow constructed wetland combined with microbial fuel cell (UCW-MFC), Ecol. Eng., 117, 120132, doi:10.1016/J.ECOLENG.2018.03.016, 2018.

Yamashita, T., Ishida, M., Ogino, A. and Yokoyama, H.: Evaluation of organic matter removal and electricity generation by using integrated microbial fuel cells for wastewater treatment., Environ. Technol., 3330(December 2015), 1-20,

15 doi:10.1080/09593330.2015.1066874, 2015.

Zhang, C.-B., Wang, J., Liu, W.-L., Zhu, S.-X., Ge, H.-L., Chang, S. X., Chang, J. and Ge, Y.: Effects of plant diversity on microbial biomass and community metabolic profiles in a full-scale constructed wetland, Ecol. Eng., 36(1), 62-68, doi:10.1016/J.ECOLENG.2009.09.010, 2010. 
Biogeosciences Discuss., https://doi.org/10.5194/bg-2018-428

Manuscript under review for journal Biogeosciences

Discussion started: 29 October 2018

(c) Author(s) 2018. CC BY 4.0 License.

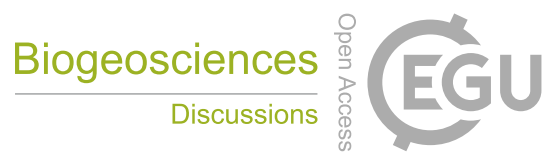

(c) (1)

Table 1: Physical-chemical characteristic of filter materials used in this study.

\begin{tabular}{lllll}
\hline Parameter & Units & PK-A $^{*}$ & PK-LSN* & Sand $^{* *}$ \\
\hline Carbon-fix & $\%$ & 95.80 & 99.43 & - \\
Sulphur & $\%$ & 1.80 & 0.54 & - \\
Nitrogen & $\%$ & 1.00 & 0.375 & - \\
Ash & $\%$ & 2.00 & 0.07 & - \\
Volatiles & $\%$ & 0.50 & 0.50 & - \\
$\mathrm{H}_{2} \mathrm{O}$ & $\%$ & 0.20 & 0.50 & - \\
Resistivity & $\Omega-\mathrm{m}$ & 0.0227 & 0.0262 & - \\
Porosity & $\%$ & $39 \pm 2$ & $55 \pm 3$ & $38 \pm 2$ \\
Density & $\mathrm{g} \mathrm{ml}{ }^{-1}$ & $1.9 \pm 0.1$ & $1.6 \pm 0.1$ & $2.62 \pm 0.1$ \\
$D_{10}$ & $\mathrm{~mm}$ & 9.47 & 3.23 & 0.46 \\
$D_{60}$ & $\mathrm{~mm}$ & 22.93 & 20.15 & 1.18 \\
\hline
\end{tabular}

*electro-conductive materials; $* *$ control material 
Biogeosciences Discuss., https://doi.org/10.5194/bg-2018-428

Manuscript under review for journal Biogeosciences

Discussion started: 29 October 2018

(c) Author(s) 2018. CC BY 4.0 License.

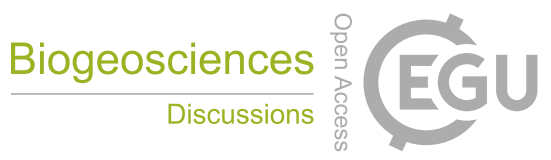

(c) (1)

Table 2: Mean values of inlet wastewater parameters along 16 weeks of operation.

\begin{tabular}{lll}
\hline Parameter & Units & Mean \\
\hline $\mathrm{pH}$ & - & $6.6 \pm 0.1$ \\
Electrical conductivity & $\mathrm{mS} \mathrm{cm}{ }^{-1}$ & $0.8 \pm 0.3$ \\
Temperature & ${ }^{\circ} \mathrm{C}$ & $16.9 \pm 1.5$ \\
Dissolved oxygen & $\mathrm{mg} \mathrm{L}-1$ & $1.4 \pm 0.81$ \\
Redox potential* & $\mathrm{mV}$ & $3.8 \pm 31.1$ \\
$\mathrm{BOD}_{5}$ & $\mathrm{mg} \mathrm{L}{ }^{-1}$ & $500 \pm 28$ \\
$\mathrm{COD}$ & $\mathrm{mg} \mathrm{L}$ & $640 \pm 34$ \\
$\mathrm{TOC}$ & $\mathrm{mg} \mathrm{L}$ & $170 \pm 49$ \\
$\mathrm{NH}_{4}-\mathrm{N}$ & $\mathrm{mg} \mathrm{L}$ & $33 \pm 3$ \\
$\mathrm{NO}_{3}-\mathrm{N}$ & $\mathrm{mg} \mathrm{L}^{-1}$ & $0.04 \pm 0.03$ \\
$\mathrm{TN}^{-1}$ & $42 \pm 9$ \\
$\mathrm{PO}_{4}-\mathrm{P}$ & $\mathrm{mg} \mathrm{L}^{-1}$ & $6 \pm 1$ \\
$\mathrm{TSS}$ & $\mathrm{mg} \mathrm{L}^{-1}$ & $341 \pm 90$ \\
\hline
\end{tabular}

* vs Standard Hydrogen Electron (corrected with $207 \mathrm{mV}$ at $25^{\circ} \mathrm{C}$ ) 
Biogeosciences Discuss., https://doi.org/10.5194/bg-2018-428

Manuscript under review for journal Biogeosciences

Discussion started: 29 October 2018

(c) Author(s) 2018. CC BY 4.0 License.

(c) (1)

Table 3: Effluent water quality parameters of tested systems along 16 weeks of operation.

\begin{tabular}{llllllll}
\hline Parameter & Unit & PK-A/P & PK-LSN/P & PK-A/NP & PK-LSN/NP & Sand/P & Sand/NP \\
\hline $\mathrm{pH}$ & - & $7.9 \pm 0.9^{\mathrm{a}}$ & $8.0 \pm 0.9^{\mathrm{a}}$ & $7.9 \pm 0.9^{\mathrm{a}}$ & $7.9 \pm 0.9^{\mathrm{a}}$ & $8.0 \pm 0.8^{\mathrm{a}}$ & $8.0 \pm 0.9^{\mathrm{a}}$ \\
Electrical conductivity & $\mathrm{mS} \mathrm{cm}{ }^{-1}$ & $0.9 \pm 0.4^{\mathrm{a}}$ & $0.9 \pm 0.5^{\mathrm{a}}$ & $0.8 \pm 0.3^{\mathrm{a}}$ & $0.8 \pm 0.4^{\mathrm{a}}$ & $0.8 \pm 0.5^{\mathrm{a}}$ & $0.8^{\mathrm{a}} 0.5^{\mathrm{a}}$ \\
Temperature & ${ }^{\circ} \mathrm{C}$ & $16.8 \pm 3.8^{\mathrm{a}}$ & $16.5 \pm 3.6^{\mathrm{a}}$ & $17.4 \pm 4.0^{\mathrm{a}}$ & $16.8 \pm 4.1^{\mathrm{a}}$ & $16.9 \pm 4.7^{\mathrm{a}}$ & $16.8 \pm 5.0^{\mathrm{a}}$ \\
Dissolved oxygen & $\mathrm{mg} \mathrm{L}^{-1}$ & $4.1 \pm 3.2^{\mathrm{a}}$ & $4.9 \pm 2.8^{\mathrm{a}}$ & $3.7 \pm 3.2^{\mathrm{a}}$ & $4.0 \pm 3.4^{\mathrm{a}}$ & $3.8 \pm 3.4^{\mathrm{a}}$ & $3.7 \pm 3.2^{\mathrm{a}}$ \\
Redox potential $^{\mathrm{a}}$ & $\mathrm{mV}$ & $229 \pm 58^{\mathrm{a}}$ & $233 \pm 52^{\mathrm{a}}$ & $220 \pm 59^{\mathrm{a}}$ & $212 \pm 67^{\mathrm{a}}$ & $224 \pm 40^{\mathrm{a}}$ & $224 \pm 32^{\mathrm{a}}$ \\
$\mathrm{BOD}_{5}$ & $\%$ & $85 \pm 11^{\mathrm{a}}$ & $86 \pm 11^{\mathrm{a}}$ & $87 \pm 11^{\mathrm{a}}$ & $87 \pm 11^{\mathrm{a}}$ & $87 \pm 9^{\mathrm{a}}$ & $86 \pm 8^{\mathrm{a}}$ \\
$\mathrm{COD}$ & $\%$ & $85 \pm 13^{\mathrm{ab}}$ & $82 \pm 12^{\mathrm{ab}}$ & $88 \pm 14^{\mathrm{a}}$ & $82 \pm 12^{\mathrm{ab}}$ & $76 \pm 11^{\mathrm{b}}$ & $76 \pm 11^{\mathrm{b}}$ \\
$\mathrm{TOC}$ & $\%$ & $77 \pm 10^{\mathrm{a}}$ & $77 \pm 8^{\mathrm{a}}$ & $79 \pm 11^{\mathrm{a}}$ & $77 \pm 9^{\mathrm{a}}$ & $76 \pm 9^{\mathrm{a}}$ & $79 \pm 7^{\mathrm{a}}$ \\
$\mathrm{NH}_{4}-\mathrm{N}$ & $\%$ & $26 \pm 15^{\mathrm{a}}$ & $28 \pm 16^{\mathrm{a}}$ & $25 \pm 15^{\mathrm{a}}$ & $24 \pm 15^{\mathrm{a}}$ & $17 \pm 13^{\mathrm{a}}$ & $17 \pm 14^{\mathrm{a}}$ \\
$\mathrm{NO}_{3}-\mathrm{N}$ & $\%$ & $17 \pm 16^{\mathrm{ab}}$ & $23 \pm 18^{\mathrm{ab}}$ & $13 \pm 13^{\mathrm{b}}$ & $21 \pm 16^{\mathrm{ab}}$ & $40 \pm 20^{\mathrm{a}}$ & $19 \pm 15^{\mathrm{ab}}$ \\
$\mathrm{TN}$ & $\%$ & $50 \pm 26^{\mathrm{a}}$ & $48 \pm 25^{\mathrm{a}}$ & $48 \pm 25^{\mathrm{a}}$ & $48 \pm 26^{\mathrm{a}}$ & $46 \pm 23^{\mathrm{a}}$ & $49 \pm 26^{\mathrm{a}}$ \\
$\mathrm{PO}_{4}-\mathrm{P}$ & $\%$ & $79 \pm 16^{\mathrm{b}}$ & $47 \pm 30^{\mathrm{c}}$ & $79 \pm 18^{\mathrm{b}}$ & $45 \pm 27^{\mathrm{c}}$ & $88 \pm 15^{\mathrm{a}}$ & $96 \pm 4^{\mathrm{a}}$ \\
$\mathrm{TSS}$ & $\%$ & $82 \pm 13^{\mathrm{b}}$ & $90 \pm 9^{\mathrm{a}}$ & $85 \pm 10^{\mathrm{ab}}$ & $87 \pm 8^{\mathrm{ab}}$ & $84 \pm 8^{\mathrm{ab}}$ & $81 \pm 14^{\mathrm{b}}$ \\
\hline
\end{tabular}

* vs Standard Hydrogen Electron (corrected with $207 \mathrm{mV}$ at $25^{\circ} \mathrm{C}$ ). Different letters indicate significant differences between tested systems. 
Biogeosciences Discuss., https://doi.org/10.5194/bg-2018-428

Manuscript under review for journal Biogeosciences

Discussion started: 29 October 2018

(c) Author(s) 2018. CC BY 4.0 License.

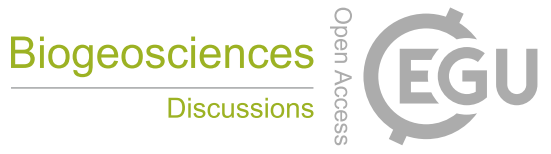

(c) (i)

(a)

(b)
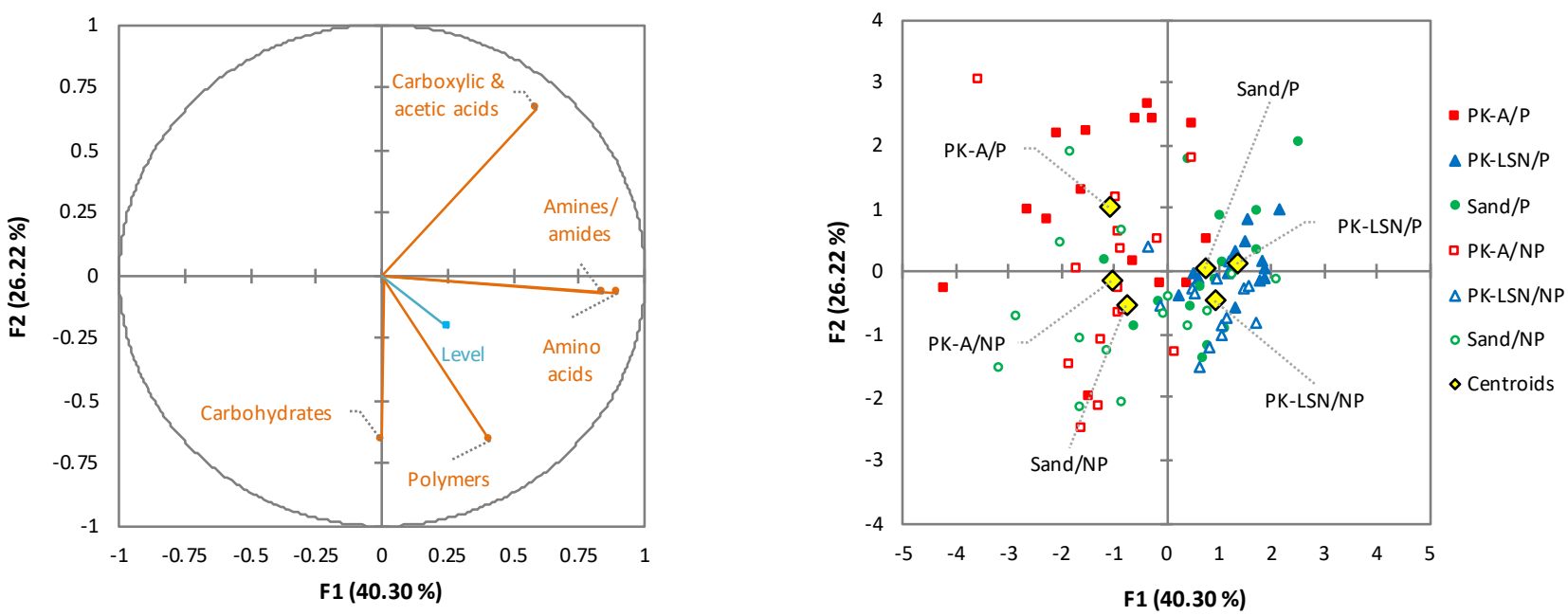

Figure 1: Principal component analysis based on Taylor transformed data of CSUP in tested systems. (a) PCA correlation circle of variables (carbon guilds and level). Carbon guilds are classified in 5 different categories (Amide/amides; Amino acids;

5 Carbohydrates; Carboxylic \& acetic acids; Polymers). (b) PCA of CSUP Taylor transformed data at 48 hours of tested systems. F1 and $\mathrm{F} 2$ are principal component factors with proportion of total variability $(\%)$. 
Biogeosciences Discuss., https://doi.org/10.5194/bg-2018-428

Manuscript under review for journal Biogeosciences

Discussion started: 29 October 2018

(c) Author(s) 2018. CC BY 4.0 License.

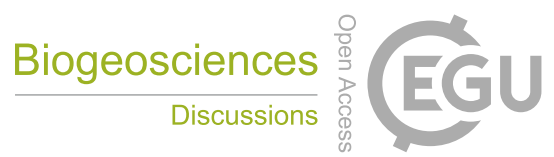

(c) (i)

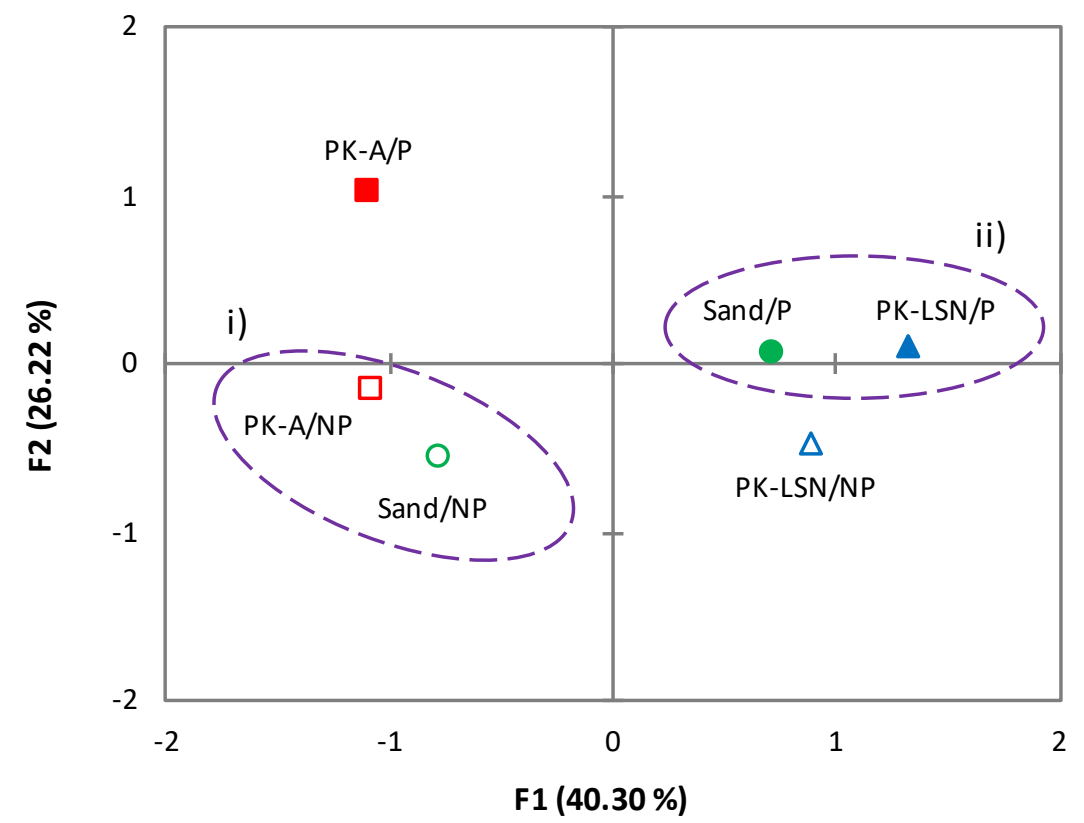

Figure 2: PCA plot of microbial community activity based on CSUP of tested systems $(n=18)$. Ellipses represent groups of systems with significant differences (Euclidean distance $-p<0.05$; PERMANOVA). 
Biogeosciences Discuss., https://doi.org/10.5194/bg-2018-428

Manuscript under review for journal Biogeosciences

Discussion started: 29 October 2018

(c) Author(s) 2018. CC BY 4.0 License.

(a)

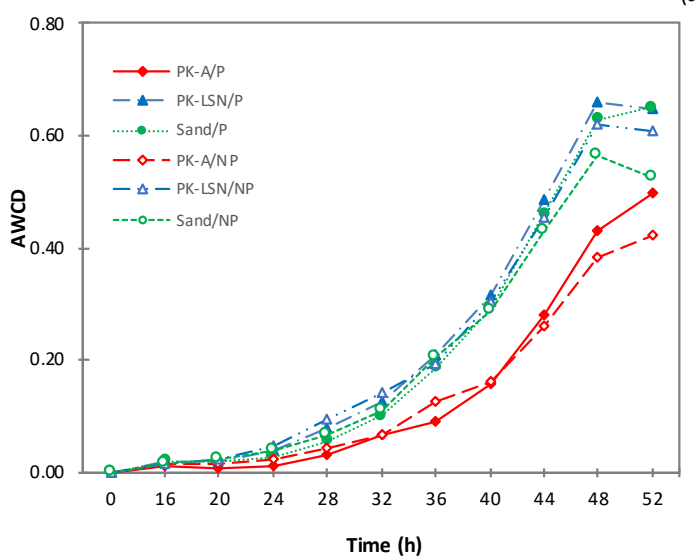

(c)

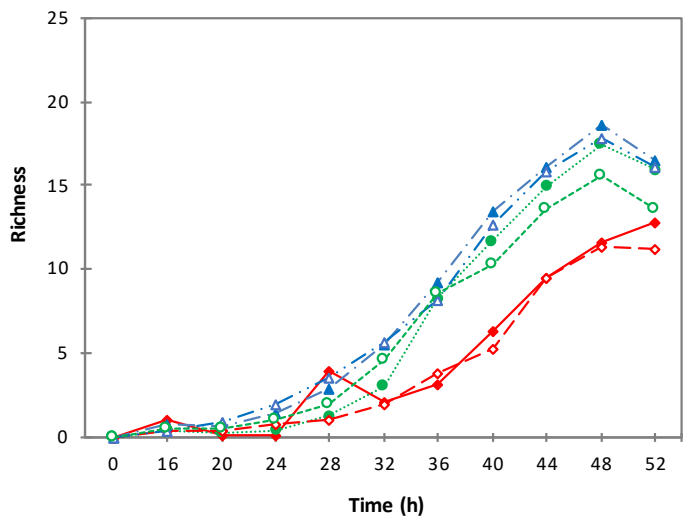

(e)

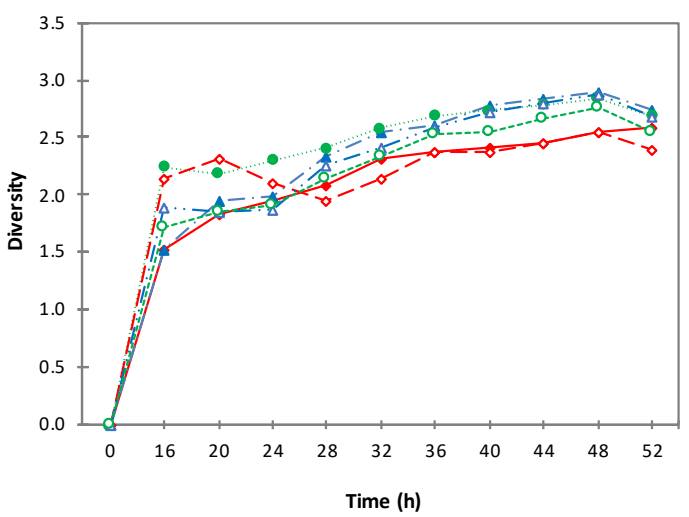

(b)

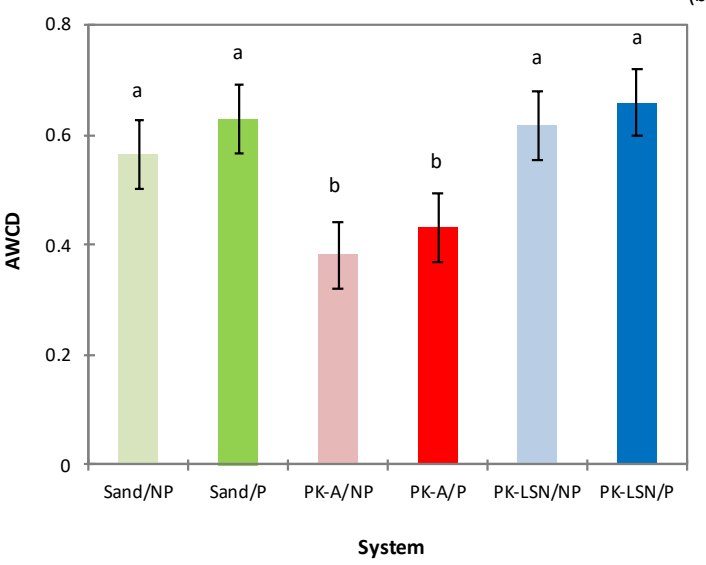

(d)

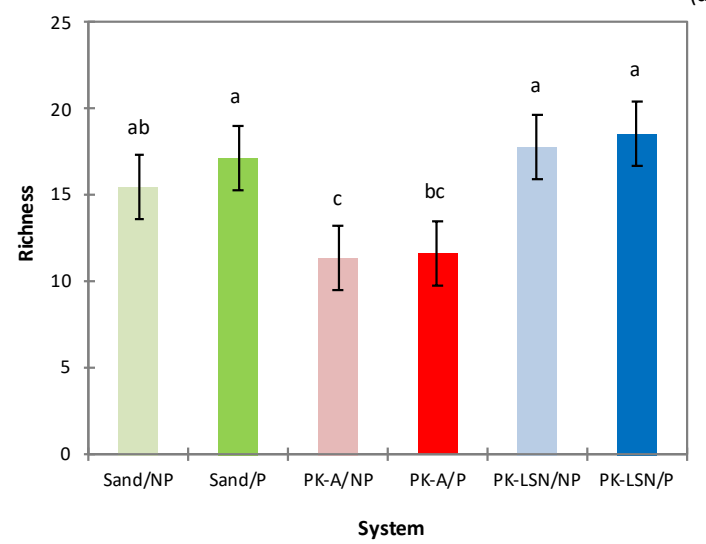

(f)

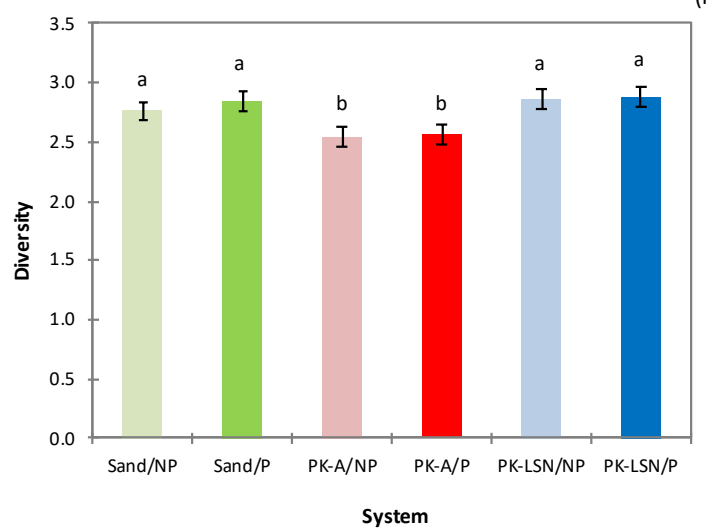

Figure 3: Microbial metabolic activity based on CSUP derived indexes (AWCD, richness and diversity) of tested systems. Left-hand side figures indicate the evolution of indexes from the beginning of the test up to 52 hours $(n=15)$. Right-hand side figures represent the indexes calculated at 48 hours; different letters indicate significant differences between tested systems $(p<0.05$; ANOVA). 
Biogeosciences Discuss., https://doi.org/10.5194/bg-2018-428

Manuscript under review for journal Biogeosciences

Discussion started: 29 October 2018

(c) Author(s) 2018. CC BY 4.0 License.

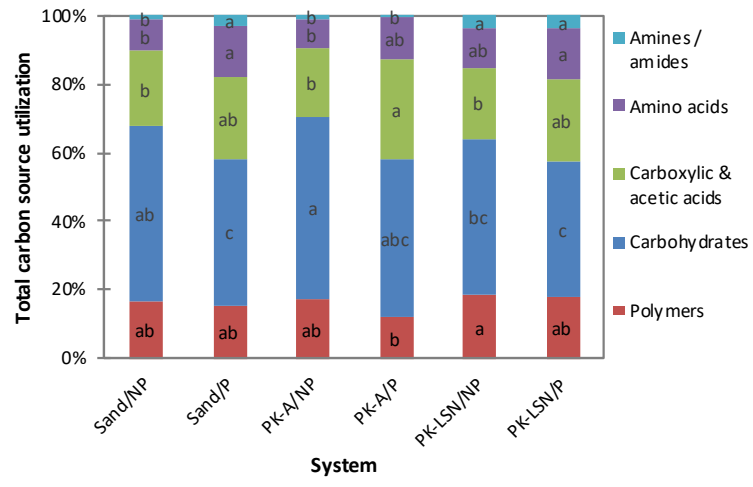

(c)

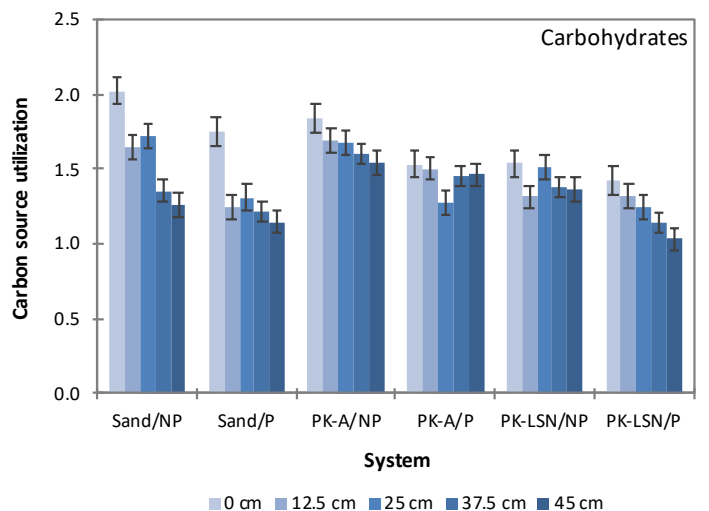

(e)

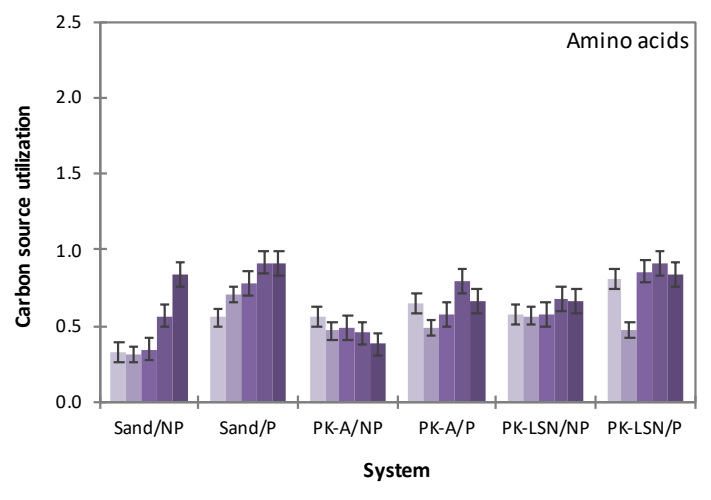

$\square 0 \mathrm{~cm}=12.5 \mathrm{~cm} \backsim 25 \mathrm{~cm}=37.5 \mathrm{~cm} \backsim 45 \mathrm{~cm}$

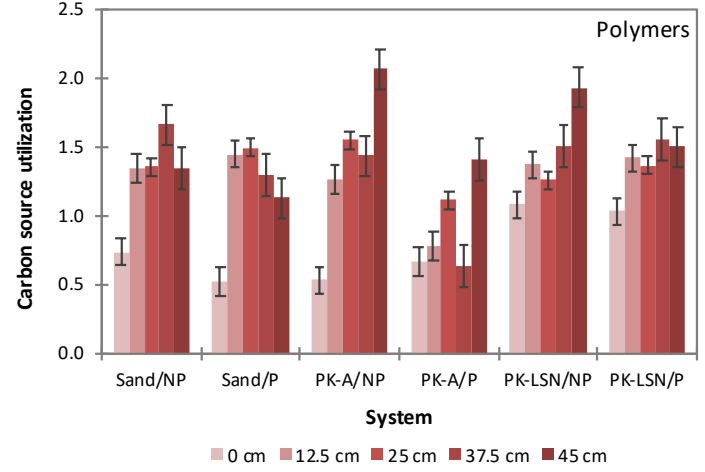

(d)

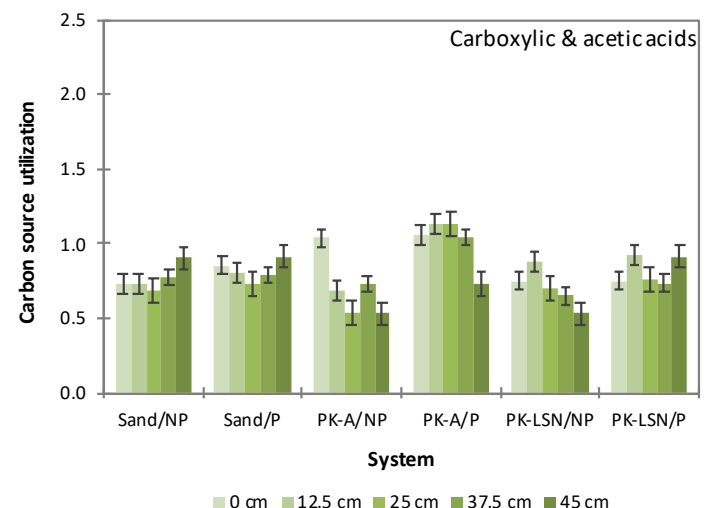

(f)

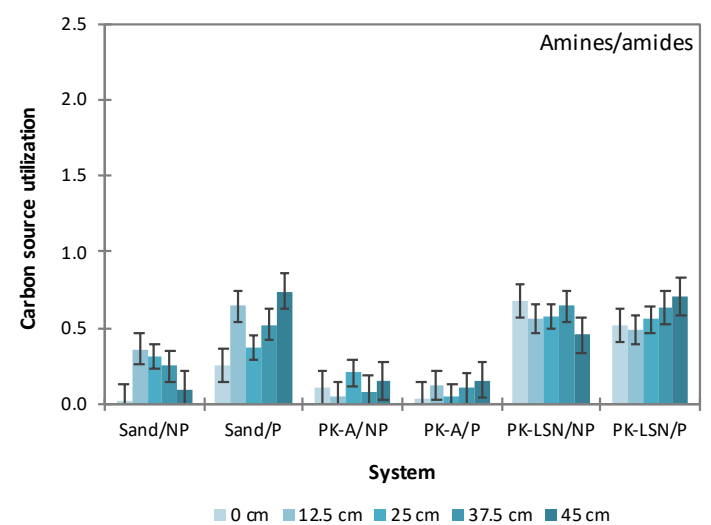

Figure 4: Carbon source utilization at 48 hours per tested systems and different heights $($ up-flow operation; bottom $=0 \mathrm{~cm}$; top $=$ $45 \mathrm{~cm}$ ). (a) Proportion of total carbon utilization per tested; different letters indicate significant differences between tested systems (ANOVA, Tukey HSD; $p<0.05$ ). Carbon sources classified in 5 different carbon gilds: (b) polymers, (c) Carbohydrates, (d) 5 Carboxylic \& acetic acids, (e) Amino acids, and (f) Amine/amides. Utilization based on average absorbance units (590 nm). 
Biogeosciences Discuss., https://doi.org/10.5194/bg-2018-428

Manuscript under review for journal Biogeosciences

Discussion started: 29 October 2018

(c) Author(s) 2018. CC BY 4.0 License.

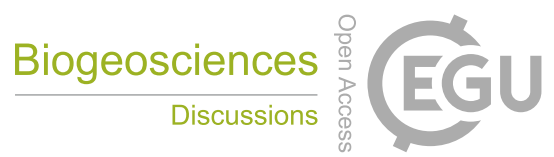

(c)

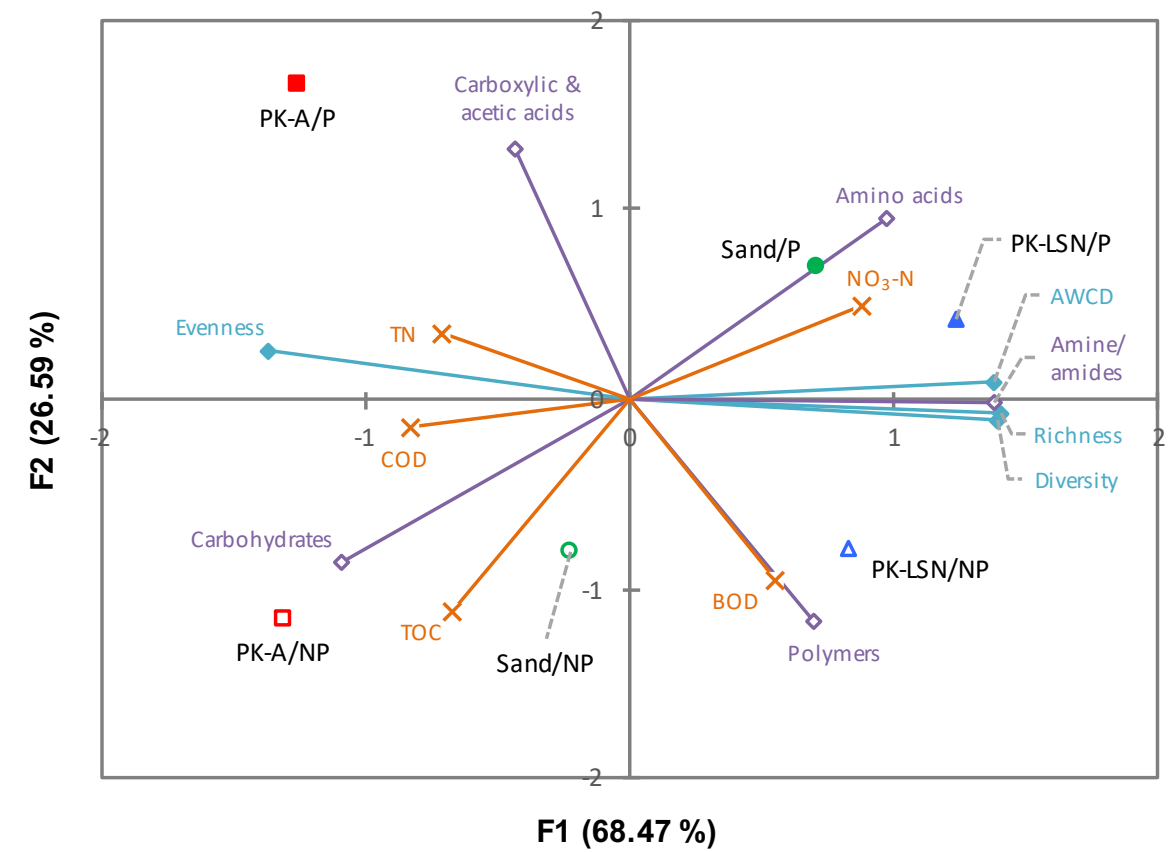

Figure 5: Correlation biplot of microbial metabolic activity indexes (AWCD, richness, diversity and evenness), carbon guild utilization (Amine/amides, Amino acids, Carbohydrates, Carboxylic \& acetic acids and Polymers) and removal efficiency of organic matter $\left(\mathrm{BOD}_{5}, \mathrm{COD}\right.$ and $\left.\mathrm{TOC}\right)$ and nitrogen $\left(\mathrm{NO}_{3}-\mathrm{N}\right.$ and $\left.\mathrm{TN}\right)$ per tested system. 